\title{
Characterization and petrologic interpretation of olivine-rich basalts at Gusev Crater, Mars
}

H. Y. McSween, ${ }^{1}$ M. B Wyatt, ${ }^{2}$ R. Gellert, ${ }^{3}$ J. F. Bell III, ${ }^{4}$ R. V. Morris, ${ }^{5}$ K. E. Herkenhoff, ${ }^{6}$ L. S. Crumpler, ${ }^{7}$ K. A. Milam, ${ }^{1}$ K. R. Stockstill, ${ }^{1}$ L. L. Tornabene, ${ }^{1}$ R. E. Arvidson, ${ }^{8}$ P. Bartlett, ${ }^{9}$ D. Blaney, ${ }^{10}$ N. A. Cabrol, ${ }^{11}$ P. R. Christensen, ${ }^{2}$ B. C. Clark, ${ }^{12}$ J. A. Crisp, ${ }^{10}$ D. J. Des Marais, ${ }^{11}$ T. Economou, ${ }^{13}$ J. D. Farmer, ${ }^{2}$ W. Farrand, ${ }^{14}$ A. Ghosh, ${ }^{1}$ M. Golombek, ${ }^{10}$ S. Gorevan, ${ }^{9}$ R. Greeley, ${ }^{2}$ V. E. Hamilton, ${ }^{15}$ J. R. Johnson, ${ }^{6}$ B. L. Joliff, ${ }^{8}$ G. Klingelhöfer, ${ }^{16}$ A. T. Knudson, ${ }^{2}$ S. McLennan, ${ }^{17}$ D. Ming, ${ }^{5}$ J. E. Moersch, ${ }^{1}$ R. Rieder, ${ }^{3}$ S. W. Ruff, ${ }^{2}$ C. Schröder, ${ }^{16}$ P. A. de Souza Jr., ${ }^{18}$

S. W. Squyres, ${ }^{4}$ H. Wänke, ${ }^{3}$ A. Wang, ${ }^{8}$ A. Yen, ${ }^{10}$ and J. Zipfel ${ }^{3}$

Received 29 April 2005; revised 15 July 2005; accepted 26 July 2005; published 6 January 2006.

[1] Rocks on the floor of Gusev crater are basalts of uniform composition and mineralogy. Olivine, the only mineral to have been identified or inferred from data by all instruments on the Spirit rover, is especially abundant in these rocks. These picritic basalts are similar in many respects to certain Martian meteorites (olivine-phyric shergottites). The olivine megacrysts in both have intermediate compositions, with modal abundances ranging up to $20-30 \%$. Associated minerals in both include low-calcium and highcalcium pyroxenes, plagioclase of intermediate composition, iron-titanium-chromium oxides, and phosphate. These rocks also share minor element trends, reflected in their nickel-magnesium and chromium-magnesium ratios. Gusev basalts and shergottites appear to have formed from primitive magmas produced by melting an undepleted mantle at depth and erupted without significant fractionation. However, apparent differences between Gusev rocks and shergottites in their ages, plagioclase abundances, and volatile contents preclude direct correlation. Orbital determinations of global olivine distribution and compositions by thermal emission spectroscopy suggest that olivine-rich rocks may be widespread. Because weathering under acidic conditions preferentially attacks olivine and disguises such rocks beneath alteration rinds, picritic basalts formed from primitive magmas may even be a common component of the Martian crust formed during ancient and recent times.

Citation: McSween, H. Y., et al. (2006), Characterization and petrologic interpretation of olivine-rich basalts at Gusev Crater, Mars, J. Geophys. Res., 111, E02S10, doi:10.1029/2005JE002477.

\section{Introduction}

[2] On Earth, abundant olivine in a basalt (such a rock is termed "picritic") is usually an indication that the basaltic

\footnotetext{
${ }^{1}$ Department of Earth and Planetary Sciences, University of Tennessee, Knoxville, Tennessee, USA.

${ }^{2}$ Department of Geological Sciences, Arizona State University, Tempe, Arizona, USA.

${ }^{3}$ Max Planck Institut für Chemie, Mainz, Germany.

${ }^{4}$ Department of Astronomy, Cornell University, Ithaca, New York, USA.

${ }^{5}$ NASA Johnson Space Center, Houston, Texas, USA.

${ }^{6}$ U.S. Geological Survey, Flagstaff, Arizona, USA.

${ }^{7}$ New Mexico Museum of Natural History and Science, Albuquerque, New Mexico, USA.

${ }^{8}$ Department of Earth and Planetary Sciences, Washington University, St. Louis, Missouri, USA

${ }^{9}$ Honeybee Robotics, New York, New York, USA.

Copyright 2006 by the American Geophysical Union. 0148-0227/06/2005JE002477\$09.00
}

magma was mantle-derived and arrived at the surface without significant fractionation. Given the dominance of olivine in planetary mantles (reflecting its high abundance in the chondritic protoplanets from which planets were assembled), mantle melting must have produced olivinebearing basalts on all the terrestrial planets. Olivine is invariably an early crystallizing phase in such magmas,

\footnotetext{
${ }^{10}$ Jet Propulsion Laboratory, California Institute of Technology, Pasadena, California, USA.

${ }^{11}$ NASA Ames Research Center, Moffett Field, California, USA

${ }^{12}$ Lockheed Martin Corporation, Littleton, Colorado, USA.

${ }^{13}$ Enrico Fermi Institute, University of Chicago, Chicago, Illinois, USA.

${ }^{14}$ Space Science Institute, Boulder, Colorado, USA

${ }^{15}$ Hawai'i Institute of Geophysics and Planetology, University of Hawai'i, Honolulu, Hawaii, USA.

${ }^{16}$ Institut für Anorganische und Analytische Chemie, Johannes Gutenberg-Universität, Mainz, Germany.

${ }^{7}$ Department of Geosciences, State University of New York, Stony Brook, New York, USA.

${ }^{18}$ Companhia Vale do Rio Doce, Rio de Janeiro, Brazil.
} 


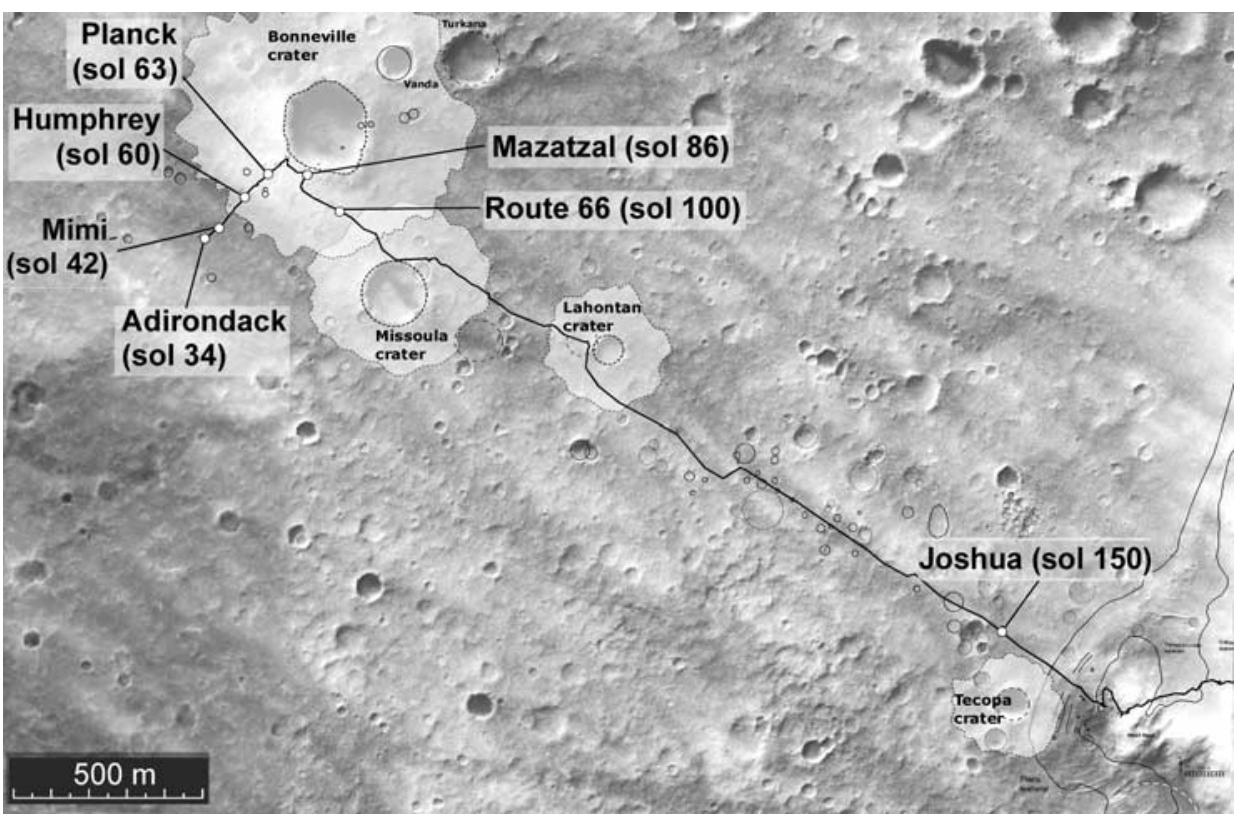

Figure 1. Traverse map showing locations of analyzed rocks described in this paper. The numbers identify the sols during which each RATed rock was analyzed by APXS.

resulting in the common occurrence of large olivine phenocrysts in lavas and their segregation to form cumulates within magma chambers. However, terrestrial experience suggests that picritic magmas rarely reach the surface, but instead are fractionated during transit from their mantle source regions.

[3] Basalts encountered near the Spirit Rover landing site in Gusev Crater $\left(14.64^{\circ} \mathrm{S} 175.36^{\circ} \mathrm{E}\right)$ contain high proportions of olivine, comparable to those in olivine-rich Martian basaltic meteorites ("olivine-phyric shergottites") and the most olivine-rich Mars surface materials inferred from orbital spectroscopy. These rocks, analyzed by the Athena instruments (science instruments onboard the Mars Exploration Rovers), may yield new insights into the Martian mantle that partially melted to produce primitive magmas. Here, we expand an earlier, preliminary description of these basalts [McSween et al., 2004] and explore possible petrologic interpretations. Comparison of Gusev picritic basalts with olivine-phyric shergottites allows a more rigorous interpretation of their origin, and comparison with regionally extensive, olivine-rich surface units mapped using thermal emission spectroscopy provides a global geologic context for olivine-bearing rocks in the Martian crust.

\section{Rock Morphologies and Distribution}

[4] Gusev is a Noachian impact crater, 160 kilometers in diameter, located in the Aeolis region of Mars. The region of the floor of Gusev Crater where Spirit landed consists of a plains unit (previously mapped as a low-albedo smooth unit on the Gusev Crater Formation [Kuzmin et al., 2000] and as low-albedo materials on the Plains thermophysical unit [Milam et al., 2003]), thought to be a minimally graded landscape decorated with impact craters and dust devil tracks [Grant et al., 2004]. Rocks scattered about the plains grade in color from dark gray to light-toned (the latter are coated with variable amounts of dust) [Bell et al., 2004]. Many faceted rocks have been sculpted by wind erosion. Some rocks are partially buried by fines, whereas others are perched on the surface. Most rocks are porphyritic with aphanitic groundmass and contain abundant vugs or vesicles, confirming their volcanic origin. The closest obvious volcanic source is Apollinaris Patera, a large volcano of Hesperian age located directly north of Gusev [Robinson and Mouginis-Mark, 1993].

[5] During much of its first 100 sols, Spirit traversed the ejecta blanket of a $210 \mathrm{~m}$ crater informally named Bonneville (Figure 1). The abundance and average size of rocks increased with proximity to the crater. These rocks were apparently excavated from Bonneville, although no rock outcroppings were observed in the crater walls. Rocks are generally angular and fragmented, but no re-cemented breccias have been recognized. Three rocks (Adirondack, Humphrey, and Mazatzal) were imaged and analyzed as-is (i.e., the natural, dust-covered surface), after brushing with the Rock Abrasion Tool (RAT) to remove surface dust, and after grinding several millimeters into the rock interior by the RAT. Several other rocks (Mimi and Planck) encountered within the Bonneville ejecta blanket were analyzed only as-is.

[6] Following exploration of the Bonneville ejecta, Spirit crossed ejecta from an adjacent crater, Missoula. Then, during Sols 111-159, Spirit traversed the intercrater plains to the Columbia Hills. Two other rocks (Route 66 and Joshua) encountered on the intercrater plains were studied. Route 66 was brushed and then analyzed, and Joshua was analyzed as-is. As Spirit approached the Hills, several highly vesicular rocks (e.g., Dagwood, Figure 2e) and others resembling scoria were observed. Unfortunately, images of these rocks were not downlinked until after the rover had passed by, so they were not analyzed.

[7] The locations of all the rocks described and analyzed here are illustrated in a traverse map (Figure 1). True-color 


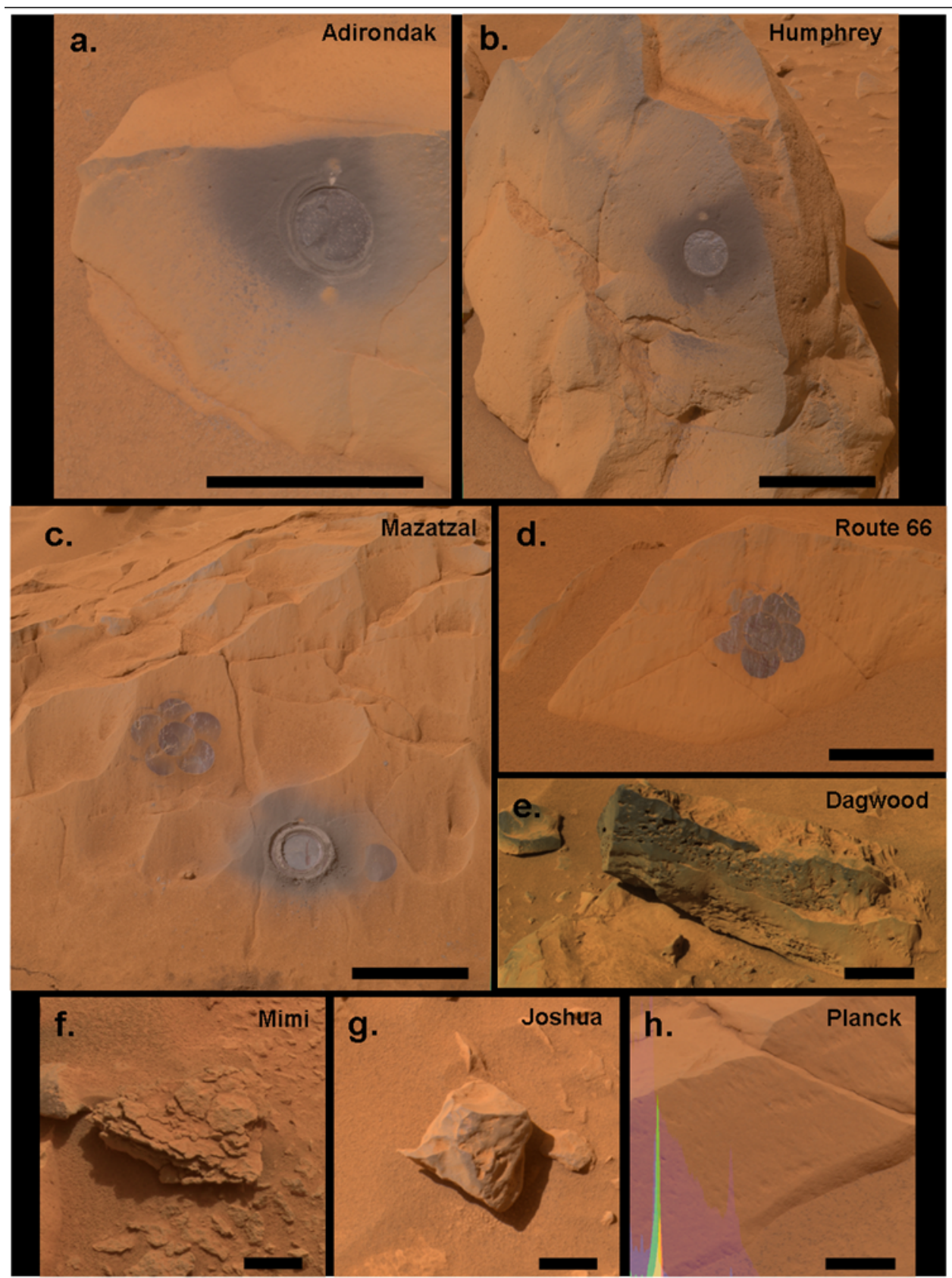

Figure 2. True-color Pancam mosaic images (Figure 2e is approximate color rendering because some filters are missing) of basaltic rocks in Gusev Crater. All rocks are named. The scale bar in each image is $10 \mathrm{~cm}$.

Panoramic Camera (Pancam) images of the rocks are shown in Figure 2.

\section{Petrography and Physical Properties of Gusev Basalts}

\subsection{Microscopic Petrography}

[8] Brushing and grinding using the RAT, followed by imaging using the Microscopic Imager (MI), allowed the discovery of alteration rinds on rocks and revealed the textures of relatively fresh rock interiors [Herkenhoff et al., 2004; McSween et al., 2004]. Although MI images are monochromatic, overlay of high-resolution Pancam images has produced false-color images that reveal more petrographic details (Figure 3) [Bell et al., 2004].

[9] The ground (RATed) surfaces of Adirondack, Humphrey, and Mazatzal all exhibit abundant, dark gray grains (Figure 3), interpreted as olivine crystals [McSween et al., 2004], in an aphanitic groundmass. (We will use the nongenetic term "megacrysts" to describe these crystals, all of which are larger than $\sim 100 \mu \mathrm{m}$, the resolution limit of MI images.) Microscopic images have sufficient resolution to permit point-counting, the first time such quantitative petrography has been attempted where the rocks and the 


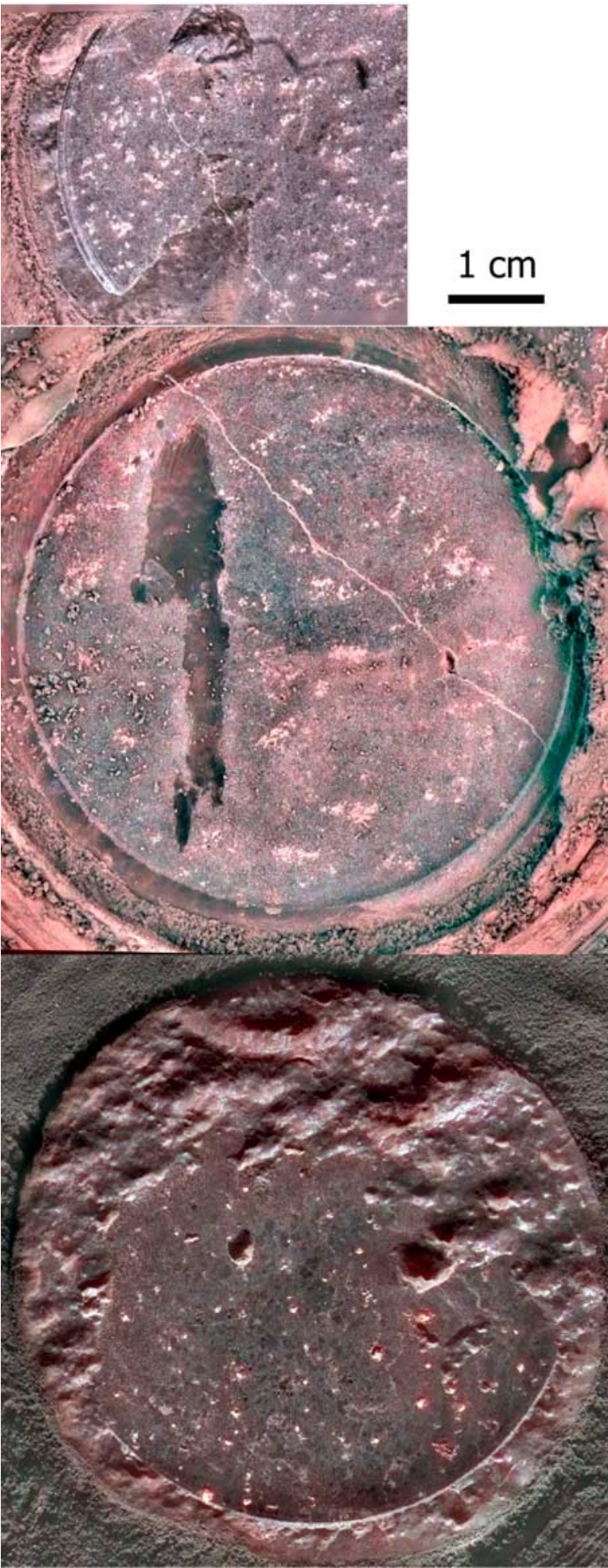

Figure 3. MI images (colorized by Pancam overlays) of RAT holes in rocks; from top to bottom: Adirondack, Mazatzal, Humphrey. Humphrey is illuminated by direct sunlight from the top, whereas images of the other rocks were acquired while they were in shadow.

operator are separated by millions of kilometers. Point counts of RATed rocks [McSween et al., 2004] indicated that megacrysts comprise approximately $9 \%, 25 \%$, and $9 \%$ by volume in Adirondack, Humphrey, and Mazatzal, re- spectively. Adirondack and Mazatzal also contain 13 and 14 volume $\%$ patches of light-colored material, respectively. The light-colored material may be an alteration product of olivine, but no obvious replacement or other physical association of the two phases is apparent.

[10] Figure 4 shows a processed image of RATed Humphrey, in which dark grain pixels have been isolated by image processing, to make clearer the shapes and distribution of these grains. The grains interpreted as olivine are heterogeneously distributed, and abundant smaller

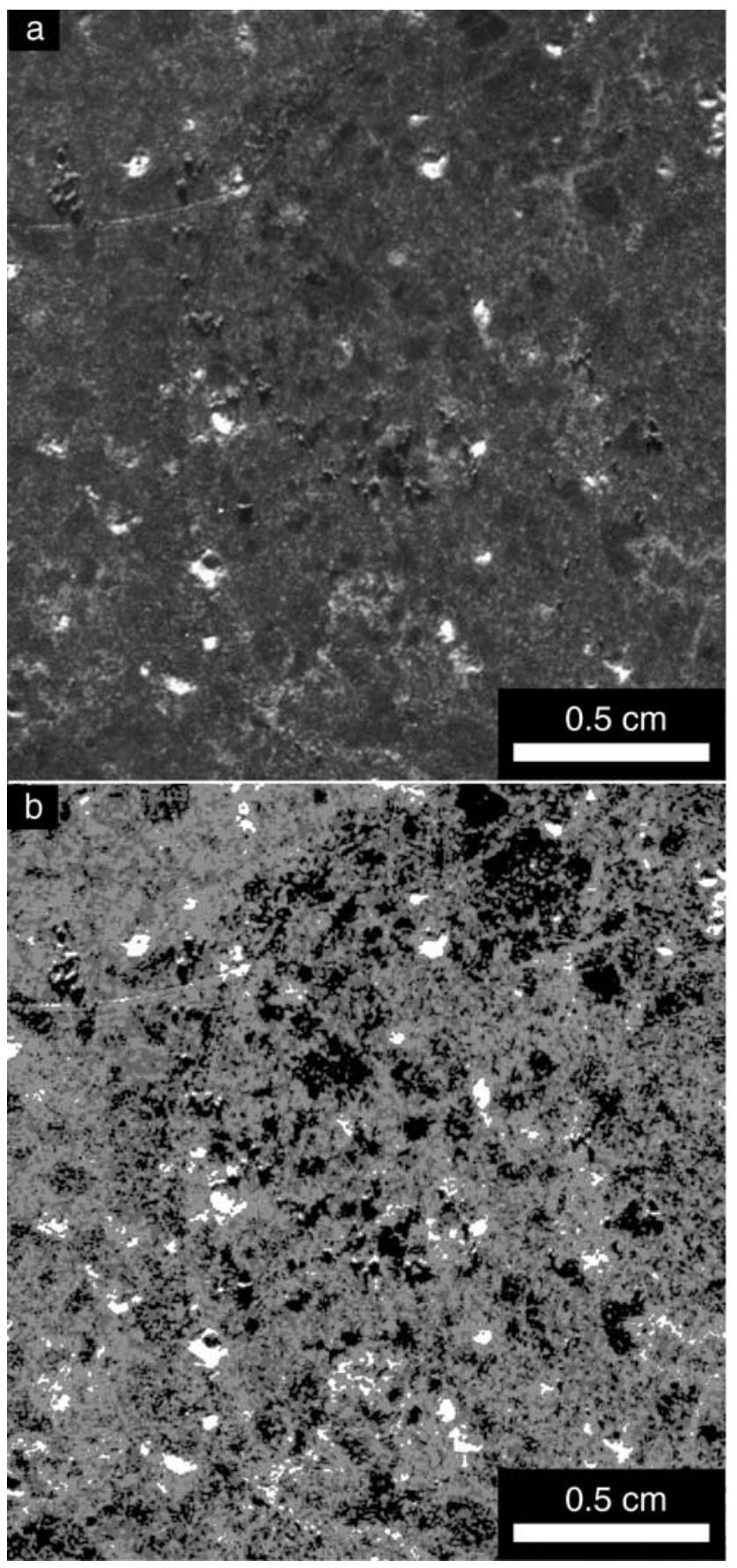

Figure 4. (a) Dark crystals in Humphrey and (b) a processed image illustrating the distribution and shapes of these grains (black). 


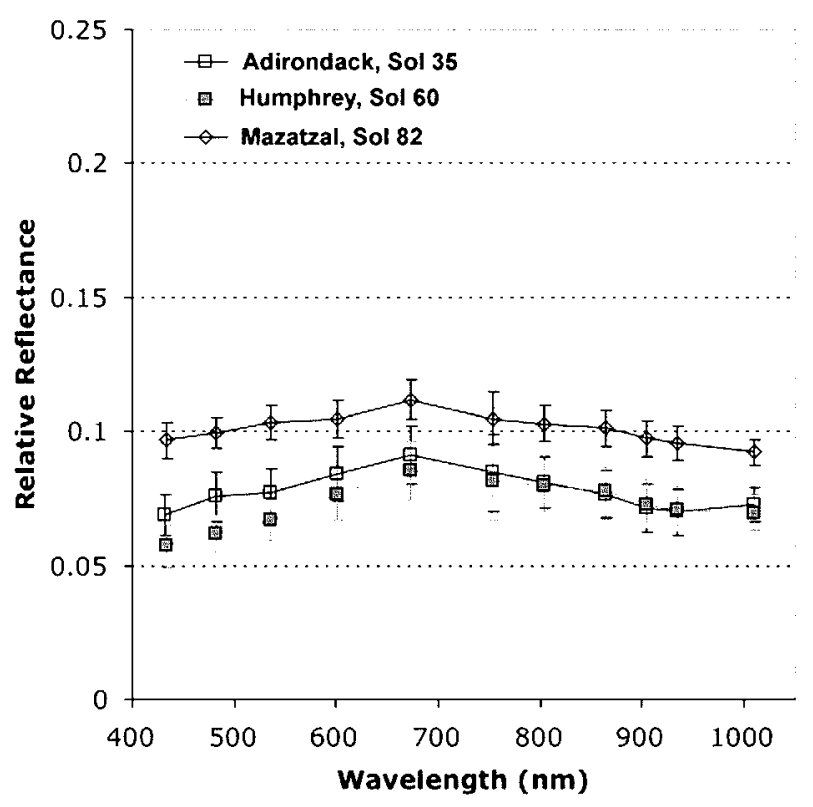

Figure 5. Pancam spectra of RAT holes ground into Adirondack (Sol 35, imaging sequence P2578), Humphrey (Sol 60, imaging sequence P2597), and Mazatzal (Sol 82, imaging sequence P2590). Errors bars represent the standard deviations of several hundred pixels within selected regions of interest.

grains, not so obvious in MI images, occur in the groundmass. None of the grains appears to be euhedral, although some subhedral outlines are apparent. Pixel counts of gray scale images may be less subjective than optical point counting on a grid, and a mode of dark grains in Humphrey determined in this way is 20 volume $\%$. However, MI images of Adirondack and Mazatzal do not have enough contrast to permit accurate pixel counts of these crystals.

[11] Tiny, irregular veins of light-colored material crosscut all three rocks. These veins cannot be fractures filled with dust, because they are not red in Pancam images. A surface rind on Humphrey, revealed by a fortuitous oblique grind from the brushed surface into the interior of the stone [see McSween et al., 2004, Figure 2; Squyres et al., 2004, Plate 12], does not contain the gray megacrysts seen in the rock's interior. This observation suggests that weathering on Mars preferentially destroys olivine. Mineralogical and chemical differences between Gusev rock surfaces and interiors support this hypothesis, which is explained by the rapid dissolution of olivine under acidic conditions [Hurowitz et al., 2006; C. Schröder et al., Evidence for olivine weathering in rocks at Gusev crater, manuscript in preparation, 2006 (hereinafter referred to as Schröder et al., manuscript in preparation, 2006)]. A more distinctive rind is visible on Mazatzal [Squyres et al., 2004, Plate 13]. The thin, dark rind underlying the dust cover is smooth and hard, and resembles a varnish. A sliver of this rind remains in the RATed image of Mazatzal in Figure 3. A light-colored vein crosscuts the varnish and thus must be younger. This dark varnish, too, is devoid of olivine. The alteration rinds on Gusev basalts have been described and interpreted elsewhere [Haskin et al., 2005] and are not the focus of this paper.

\subsection{Grinding Hardness}

[12] The RAT monitored the energy expended during grinding. The grinding energy, divided by the volume of rock removed, is a function of several physical properties, but especially rock hardness. Because secondary alteration minerals are usually soft, grinding hardness is probably a proxy for degree of alteration. Grinding hardness for the three rocks analyzed, expressed in $\mathrm{J} / \mathrm{mm}^{3}$, is approximately as follows: Adirondack - 64, Humphrey - 94, and Mazatzal - 61 [Bartlett et al., 2005]. The hardness of Humphrey suggests that it is the least altered of these rocks, consistent with the MI observation that it contains the highest proportion of olivine.

\section{Olivine Identification and Accompanying Mineralogy in Gusev Basalts}

[13] Olivine is the only mineral identified or inferred from data by all the Athena instruments on the Spirit Rover. The synergy provided by the Pancam, Mini Thermal Emission Spectrometer (MiniTES), Mössbauer Spectrometer (MB), and Alpha Particle X-ray Spectrometer (APXS) allow documentation of the mineralogy of these rocks.

\subsection{Pancam Multispectral Observations}

[14] Pancam 11-wavelength (430 to $1009 \mathrm{~nm}$ ) spectra of RAT holes ground into Adirondack, Humphrey, and Mazatzal are shown in Figure 5. These relative reflectance (radiance factor or "I/F") spectra were calibrated using near-simultaneous measurements of the Pancam calibration target [Bell et al., 2006]. These are the lowest reflectivity, least red spectral units identified by Pancam at the Gusev landing site. The low reflectance and lack of a steep increase in reflectivity toward the red wavelengths indicate that the RAT holes are not contaminated with aeolian dust and imply the almost complete absence of ferric minerals within the shallow $(\sim 5-7 \mathrm{~mm})$ interiors of these rocks.

[15] The reflectance maximum near $650-700 \mathrm{~nm}$ and the negative spectral slope from $\sim 700$ to $1000 \mathrm{~nm}$ are both consistent with the iron mineralogy of these rock interiors being dominated by ferrous silicate phases like olivine or pyroxene [e.g., Adams, 1974; Morris et al., 2000; Cloutis and Bell, 2003]. The Pancam spectra do not reveal an unambiguous near-IR reflectivity minimum that could be used to provide a strong constraint on the specific ferrous mineralogy. However, the presence of a weak minimum between 900 and $1000 \mathrm{~nm}$ in the Adirondack and Humphrey spectra could be consistent with the presence of low-calcium pyroxene, and may indicate a subtle difference in mineralogy between these two rocks and Mazatzal. In addition, the decrease in reflectance toward the longer wavelengths observed in all three spectra could be the high-energy wing of a mineral absorption band centered in the near-infrared beyond Pancam's wavelength range. If so, this feature could be consistent with the presence of either olivine or highcalcium pyroxene, both of which exhibit absorptions in the 1000-1300 nm wavelength region.

[16] Further support for a ferrous mineral signature in these rock spectra comes from comparison of Pancam multispectral parameters to those derived from laboratory 


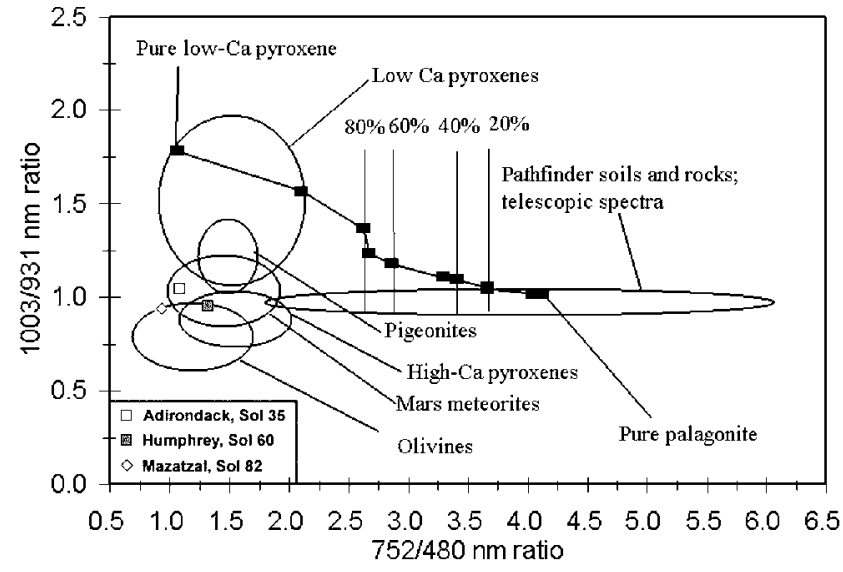

Figure 6. Pancam RAT hole multispectral parameters compared to laboratory ferric and ferrous minerals characterized by Cloutis and Bell [2003]. The laboratory measurements were resampled to the Imager for Mars Pathfinder filter bandpasses, which are essentially the same as the Pancam bandpasses for the parameters plotted here. The black rectangles connected by the line are parameters derived from ferrous-ferric mixtures.

ferrous and ferric minerals by Cloutis and Bell [2003] for similar multispectral measurements (Figure 6). Pancam data for the three RAT holes examined here plot in the same parameter space as olivine, high-calcium pyroxene, and the Martian meteorites. Similar constraints on the ferrous mineralogy can be inferred from comparison of the Pancam data to additional laboratory ferric and ferrous minerals studied by Morris et al. [2000].

[17] While Pancam data cannot uniquely determine the ferrous mineralogy of these rocks, the implied evidence for olivine and/or pyroxenes is consistent with MiniTES and Mössbauer identification of these phases (see sections 4.2 and 4.3). Furthermore, the lack of evidence for ferric phases, both within the average RAT hole Pancam spectra and in Pancam spectra from small numbers of pixels associated with vugs and veins within the exposed rock interiors, implies that there has been only very limited alteration of these rocks, even within the relatively nearsurface regions exposed by the RAT.

\subsection{MiniTES Spectral Observations}

[18] MiniTES measurements of non-dusty rocks on the plains of Gusev demonstrate that all the rocks exhibit similar spectral shapes (Figure 7a). The middle portions of these spectra $\left(\sim 1200-800 \mathrm{~cm}^{-1}\right)$ are difficult to model with mineral spectra alone because of a high degree of atmospheric spectral contribution caused by downwelling radiance from a relatively warm atmosphere onto cold rocks. However, the low-wave number region $\left(<600 \mathrm{~cm}^{-1}\right)$ is much less affected (S. W. Ruff et al., The rocks of Gusev crater as viewed by the Mini-TES instrument, manuscript in preparation, 2006). It is in this range that a prominent emissivity peak centered at $\sim 425 \mathrm{~cm}^{-1}$ is evident in all of the spectra. As shown by Christensen et al. [2004], this peak is best fit by olivine with a composition in the range of $\mathrm{Fo}_{35-60}$ (expressed as mol.\% of the forsterite $\mathrm{Mg}_{2} \mathrm{SiO}_{4}$ end-member).
[19] Figure 7b shows a MiniTES measured emissivity spectrum and linearly deconvolved modeled spectral fit of a representative warm, dark disturbed soil in Gusev Crater. The measured spectrum is an average of 200 individual spectra and is corrected for downwelling atmospheric radiance and contributions of fine-grained surface dust [Christensen et al., 2004]. The abundances of derived minerals that fit to the measured spectrum have been summed into mineral groups with accuracies of 5 to 10 volume $\%$. The end-member spectra shown are scaled by these abundances to show how each contributes to the measured spectrum. The basaltic soil is dominated by approximately equal amounts of plagioclase $(50 \%)$ and pyroxene $(20 \%$ high-calcium clinopyroxene and $20 \%$ pigeonite) with detectable amounts of olivine $(10 \%)$. The olivine composition of the soils is $\mathrm{Fo}_{45 \pm 5}$ to 10 , which agrees with the APXS-derived normative olivine composition (section 4.4). The derived bulk composition of Gusev soils also agrees with the compositions of basalts derived from Mars Global Surveyor (MGS) Thermal Emission Spectrometer (TES), which range from 45$50 \%$ plagioclase, $25-35 \%$ high-calcium clinopyroxene, 10 $15 \%$ olivine, and $10-15 \%$ sheet silicates and/or amorphous phases [Christensen et al., 2000] (section 5.2). However, the modal mineralogy of the local soils does not coincide with those inferred for the rocks.

\subsection{Mössbauer Observations}

[20] Mössbauer spectra of the rocks are characterized by two $\mathrm{Fe}^{2+}$ doublets, interpreted as olivine and probably pyroxene, and a $\mathrm{Fe}^{3+}$ doublet, suggested to represent nanophase ferric iron oxide and magnetite [Morris et al., 2004]. Ground rock interiors show the least $\mathrm{Fe}^{3+}$ associated with nanophase oxide, implying that weathering is not extensive. Least squares fitting of the spectra allow estimates of the molar $\mathrm{Fe}^{2+} / \mathrm{Fe}$ (total) values for RATed rocks: Adirondack 0.83 , Humphrey 0.84, and Mazatzal 0.90, all \pm 0.04 , similar to values for terrestrial basalts $(0.85-0.90)$.

[21] The composition of olivine was estimated from the temperature dependence of the Mössbauer quadrupole splitting. The estimated composition is $\sim \mathrm{Fo}_{60}$ [Morris et al., 2004]; this composition assumes a linear relationship between composition and the splitting parameter, and no uncertainty was reported. $\mathrm{Fo}_{60}$ is slightly more magnesian than the olivine composition estimated from MiniTES spectra or APXS norm calculations (see section 4.4). Because the Mössbauer spectrometer analyzes a deeper volume of material than MiniTES or APXS, its spectra may sample a different proportion of olivine core compositions, which would be magnesian if the crystals are zoned.

\subsection{APXS Measurements and Norms}

[22] Preliminary APXS analyses of Gusev rocks [Gellert et al., 2004] have recently been revised [Gellert et al., 2006] on the basis of a new calibration. Sensor heads on the two rovers were inadvertently switched just before launch, and that belated discovery necessitated recalibration. Consequently, the results reported here differ slightly (about $10 \%$ relative for oxides of the low atomic number elements, generally within the quoted uncertainties of Gellert et al. [2004]) from those of the preliminary report; $\mathrm{Na}_{2} \mathrm{O}$ and $\mathrm{MgO}$ are lower by $\sim 1$ weight $\%$ absolute, and $\mathrm{Al}_{2} \mathrm{O}_{3}$ is higher by the same amount. For other elements, there are no 

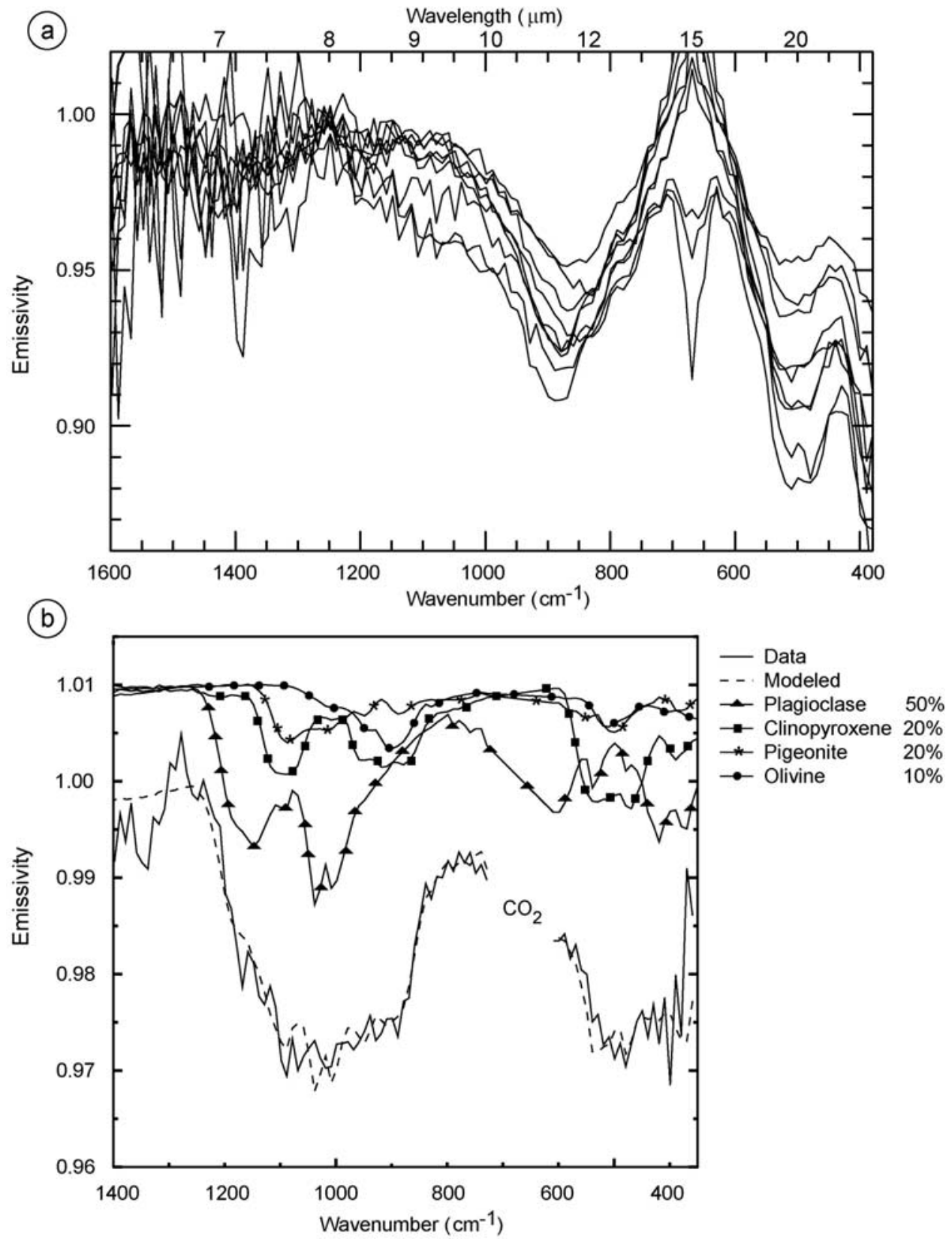

Figure 7. MiniTES spectra of Gusev rocks and soils. (a) Spectra of non-dusty rocks are similar, demonstrating that all the rocks on the plains have similar compositions. The absorption band at $\sim 500 \mathrm{~cm}^{-1}$ results from olivine. (b) Deconvolved spectra of average disturbed soils on the Gusev plains probably reflect the mineralogy of the rocks. $\mathrm{CO}_{2}$ marks the position of the atmospheric $\mathrm{CO}_{2}$ band.

discernable differences, except those arising from re-nomalization. The revised APXS analyses and uncertainties for Adirondack, Humphrey, and Mazatzal (natural, brushed, and RATed) are tabulated by Gellert et al. [2006].

[23] Plots of oxides versus $\mathrm{SO}_{3}$, originally developed to correct for dust coverings on Mars Pathfinder rocks [Rieder et al., 1997], are illustrated for Gusev basalts and soils in Figure 8. Pathfinder rocks were variably coated with dust, and clean rock compositions were estimated by extrapolating the trends to 0.3 wt. $\% \mathrm{~S}\left(0.75\right.$ wt. $\left.\% \mathrm{SO}_{3}\right)$, the average sulfur abundance (as igneous troilite) in Martian basaltic meteorites [Brückner et al., 2003]. Surface (as-is), brushed, and RATed rock compositions, which have progressively less $\mathrm{SO}_{3}$, are shown by small symbols in Figure 8 . For most elements, the brushed compositions do not lie on straight lines connecting the RATed compositions to surface or soil compositions. Compositions of the brushed areas represent thin alteration rinds seen in MI imagery and are distinct from the soil compositions. However, natural rock surface compositions commonly plot along mixing lines between brushed and soil compositions.

[24] Analyses for Route 66, Mimi, Planck, and Joshua are also given by Gellert et al. [2006] and plotted in Figure 8 . Soil analyses form a cluster at $\sim 6$ wt. $\% \mathrm{SO}_{3}$, with a trend to lower $\mathrm{SO}_{3}$ (presumably representing admixture of local rock fragments) and another to higher $\mathrm{SO}_{3}$ (apparently represent- 

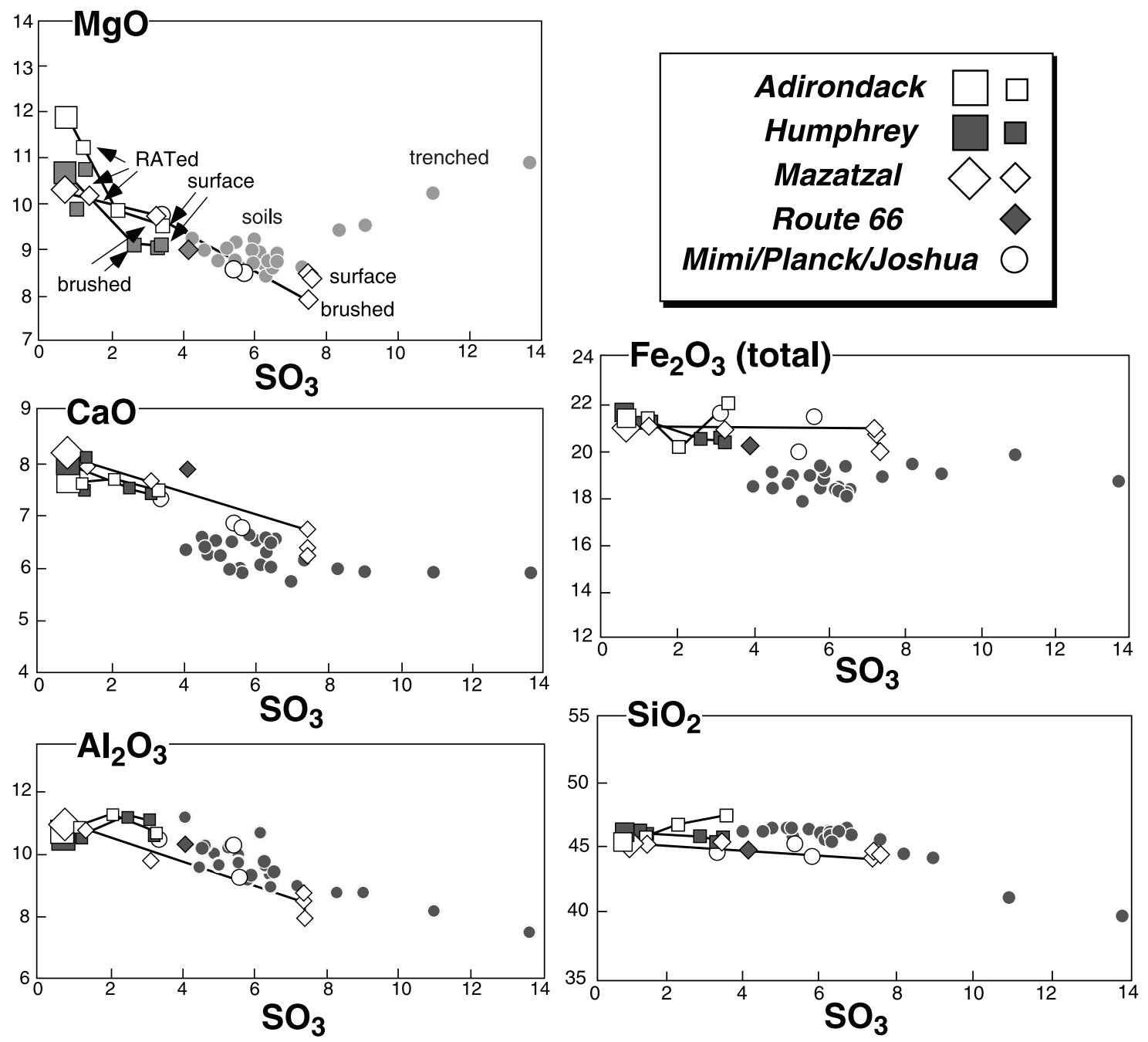

Figure 8. APXS analyses of rocks and soils [Gellert et al., 2006], oxides plotted versus $\mathrm{SO}_{3}$. Clean rock compositions (large symbols) are derived by extrapolating from brushed compositions through RATed compositions to $0.3 \mathrm{wt} \%$ sulfur $\left(0.75 \mathrm{wt} \% \mathrm{SO}_{3}\right)$. Route 66 (RATed composition) is distinguished from Mimi, Planck, and Joshua (unbrushed compositions).

ing addition of $\mathrm{MgSO}_{4}$ ) seen in subsurface soils exposed in trenches [Haskin et al., 2005].

[25] The larger symbols in Figure 8 represent end-member rock compositions determined by extrapolation from the brushed through the RATed values to 0.75 weight $\% \mathrm{SO}_{3}$, equivalent to 0.83 weight $\% \mathrm{FeS}$. Visual inspection showed that grinding commonly did not remove all vestiges of the rinds, so this extrapolation corrects for any remaining rind in RAT holes. The extrapolated rock compositions are given in Table 1. Rock compositions based on the new calibration are only slightly different from those reported by $\mathrm{McS}$ Sween et al. [2004]; $\mathrm{MgO}$ and $\mathrm{Na}_{2} \mathrm{O}$ are lower and $\mathrm{Al}_{2} \mathrm{O}_{3}$ is higher. These rock compositions plot on the boundary separating the basalt and picrobasalt fields in the alkalis-silica diagram used to classify volcanic rocks (Figure 9), hence our use of the term "picritic basalt" to describe these rocks.

\subsection{Summary of Constraints on Rock Mineralogy}

[26] Calculated CIPW norms for the new end-member rock compositions are given in Table 1. These calculations assume $\mathrm{Fe}^{2+} / \mathrm{Fe}$ (total) ratios for RATed rocks as determined by Mössbauer measurements [Morris et al., 2004], as described above. The normative mineral proportions for the three basalts are illustrated in Figure 10.

[27] These data compare favorably with the mineral assemblage identified by Mössbauer spectroscopy, but the inferred relative proportions of minerals differ. Proportions of iron-bearing minerals (relative peak areas\% [Morris et al., 2004], assumed to be volume $\%$, and renormalized for noniron-bearing minerals (plagioclase, apatite) in calculated norms) for Adirondack/Humphrey/Mazatzal, respectively, are olivine $35 / 35 / 40$, pyroxenes $22 / 22 / 22$, and oxides $15 /$ $14 / 9$. However, it is not possible to compare directly the normative mineral abundances (weight $\%$,) with Mössbauer abundances (volume\%).

[28] As noted earlier, MiniTES spectra for rocks cannot be deconvolved because of down-welling radiance effects, but olivine is confirmed. Pancam spectra are consistent with the presence of olivine and/or pyroxenes. Quantitative MI image analysis of dark crystals inferred to be olivine in Humphrey is similar to the normative olivine content, but olivine point counts in the other rocks are considerably lower. 
Table 1. Extrapolated End-Member Chemical Compositions and Calculated Norms for Gusev Basalts ${ }^{\mathrm{a}}$

\begin{tabular}{lrrr}
\hline & Adirondack & Humphrey & Mazatzal \\
\hline & \multicolumn{3}{c}{ Oxides, wt\% } \\
$\mathrm{SiO}_{2}$ & 45.30 & 45.85 & \\
$\mathrm{TiO}_{2}$ & 0.49 & 0.58 & 45.55 \\
$\mathrm{Al}_{2} \mathrm{O}_{3}$ & 10.42 & 10.4 & 0.57 \\
$\mathrm{Fe}_{2} \mathrm{O}_{3}$ & 3.63 & 3.36 & 10.72 \\
$\mathrm{Cr}_{2} \mathrm{O}_{3}$ & 0.62 & 0.67 & 2.11 \\
$\mathrm{FeO}$ & 15.71 & 15.67 & 0.59 \\
$\mathrm{MnO}$ & 0.42 & 0.42 & 16.83 \\
$\mathrm{MgO}$ & 11.90 & 10.67 & 0.43 \\
$\mathrm{CaO}$ & 7.76 & 8.15 & 10.34 \\
$\mathrm{Na}$ & 2.09 & 2.35 & 8.23 \\
$\mathrm{~K}_{2} \mathrm{O}$ & 0.03 & 0.09 & 2.62 \\
$\mathrm{P}_{2} \mathrm{O}_{5}$ & 0.54 & 0.59 & 0.11 \\
$\mathrm{FeS}$ & 0.83 & 0.83 & 0.63 \\
$\mathrm{Total}$ & 99.81 & 99.79 & 0.83 \\
& & & 99.63
\end{tabular}

\begin{tabular}{lrrr}
\multicolumn{3}{c}{ Norms, $w t^{\%}$} & \\
plag & $36.8\left(\mathrm{An}_{52}\right)$ & $38.0\left(\mathrm{An}_{46}\right)$ & $40.0\left(\mathrm{An}_{43}\right)$ \\
or & 0.18 & 0.53 & 0.65 \\
$a b$ & 17.68 & 19.88 & 22.17 \\
$a n$ & 18.97 & 17.57 & 17.17 \\
$d i$ & 13.17 & 15.70 & 16.23 \\
$h y$ & 18.86 & 16.60 & 7.42 \\
$o l$ & $21.7\left(\mathrm{Fo}_{52}\right)$ & $20.2\left(\mathrm{Fo}_{49}\right)$ & $28.6\left(\mathrm{Fo}_{45}\right)$ \\
fo & 11.18 & 9.86 & 12.89 \\
fa & 10.51 & 10.33 & 15.73 \\
$m t$ & 5.26 & 4.87 & 3.06 \\
$c m$ & 0.91 & 0.99 & 0.87 \\
$i l$ & 0.93 & 1.10 & 1.08 \\
ap & 1.28 & 1.40 & 1.49 \\
\hline
\end{tabular}

${ }^{a}$ Rock end-member compositions were calculated by subtracting from the RAT-abraded APXS compositions enough of the brushed APXS analyses ( $31 \%, 21 \%$, and $13 \%$ for Adirondack, Humphrey, and Mazatzal, respectively) to reduce residual $\mathrm{S}$ to $0.3 \mathrm{wt} \%$. After conversion of $\mathrm{S}$ to $\mathrm{FeS}(0.83 \mathrm{wt} \%)$, the remaining iron was partitioned between $\mathrm{FeO}$ and $\mathrm{Fe}_{2} \mathrm{O}_{3}$ on the basis of Mössbauer measurements of molar $\mathrm{Fe}^{3+} / \mathrm{Fe}$ (total) of $0.17,0.16$, and 0.10 for the three rocks, respectively [Morris et al., 2004]. Compositions were recast into CIPW normative mineralogy after removing FeS. Norm abbreviations are plag, plagioclase; or, orthoclase; $a b$, albite; $a n$, anorthite; $d i$, diopside; $h y$, hypersthene; ol, olivine; $f o$, forsterite; $f a$, fayalite; $m t$, magnetite; $\mathrm{cm}$, chromite; $i l$, ilmenite; ap, apatite.

[29] Of the minerals present, olivine has the most tightly constrained composition. Normative olivine compositions (illustrated by arrows) are compared with olivine compositions determined by Mössbauer and MiniTES spectra for the same rocks in the lower part of Figure 11a. The average normative olivine composition for all three rocks is $\sim \mathrm{Fo}_{49}$. Olivine abundances are compared in the lower part of Figure 11b.

\section{Comparisons With Martian Meteorites and Orbital Spectroscopic Data}

\subsection{Olivine-Phyric Shergottites}

[30] Olivine-phyric shergottites [Goodrich, 2002] are extrusive pyroxene-plagioclase basalts with porphyritic textures of large olivine crystals (megacrysts). Related plutonic ultramafic rocks that also contain olivine are called lherzolitic shergottites, and related basalts without olivine megacrysts are called basaltic shergottites. Olivine-phyric shergottites provide the most direct analogy to the Gusev picritic basalts.

[31] The compositions and proportions of olivine in olivine-phyric shergottites and descriptive references for these meteorites are summarized in Table 2. A backscattered electron (BSE) image of the SAU 005 meteorite (Figure 12) shows a similar texture to those of Gusev basalts. The olivine megacrysts in these meteorites are strongly zoned with magnesian cores and ferroan rims, and their measured compositional ranges (bars in Figure 11a) generally overlap the average composition of olivine in Gusev basalts. This comparison is hampered by the fact that we do not know whether Gusev olivines are also zoned. If they are, as seems likely, their compositional ranges may be approximated by the compositions of olivines formed between the liquidus and solidus in a MELTS crystallization calculation (see section 6.1). This range $\left(\mathrm{Fo}_{81-55}\right)$ is also illustrated by a gray bar labeled MELTS in Figure 11a. To allow a more straightforward comparison, the calculated normative olivine compositions for olivine-phyric shergottites (calculated assuming bulk rock $\mathrm{Fe}^{2+} / \mathrm{Fe}($ total $)=0.84$, as measured for Humphrey [Morris et al., 2004]) are illustrated by shaded circles in Figure 11a. The shergottite olivines appear to be more magnesian than those in Gusev basalts, but the differences are not pronounced. The compositions of olivines in lherzolitic shergottites (shaded box in Figure 11a) are also more magnesian. The volume proportions of olivine megacrysts in Gusev basalts and olivine-phyric shergottites also overlap (Figure 11b and Table 2). These similarities support the hypothesis that olivine-phyric shergottites and Gusev basalts may have had a similar petrogenesis. What insights can be gained from this comparison?

[32] It is not clear whether the gray megacrysts (presumed to be olivine) in Gusev basalts are phenocrysts that grew from the magma or are foreign crystals added to the magma [McSween et al., 2004]. Likewise, there has been considerable controversy about the origin of the megacrysts in olivine-phyric shergottites. Some studies have focused on the ragged and sometimes embayed grain boundaries, the presence of occasional polymineralic grains, and the compositions of olivine cores that are generally too iron-rich to have been in equilibrium with the bulk-rock compositions. Such studies have also noted that ferroan rims occur on megacrysts where they are in contact with groundmass, suggesting disequilibrium with the enclosing magma. On the basis of such observations, the olivines have been suggested to be xenocrysts (foreign crystals incorporated into the magma) [Steele and Smith, 1982; McSween and Jarosewich, 1983; Wadhwa et al., 2001; Koizumi et al., 2004] or cumulates (crystals accumulated and concentrated from a large batch of magma) [Barrat et al., 2002; Koizumi et al., 2004]. In these models, olivine has also been suggested to have been partly resorbed and assimilated by the host magmas. The high thermal energy required to assimilate olivine crystals poses a considerable problem, and several alternatives have been proposed. Wadhwa et al. [1994] suggested that the megacrysts might have been introduced by mixing an olivine phenocryst-bearing magma with a basaltic shergottite magma. Mittlefehldt et al. [1999] favored the idea that the megacrysts were residual crystals from impact melting, and Folco et al. [2000] proposed that they were restites from partial melting of lherzolitic shergottites.

[33] Recent recovery of new olivine-phyric shergottites with distinct textures and more magnesian olivine core compositions supports another interpretation. Some of these 


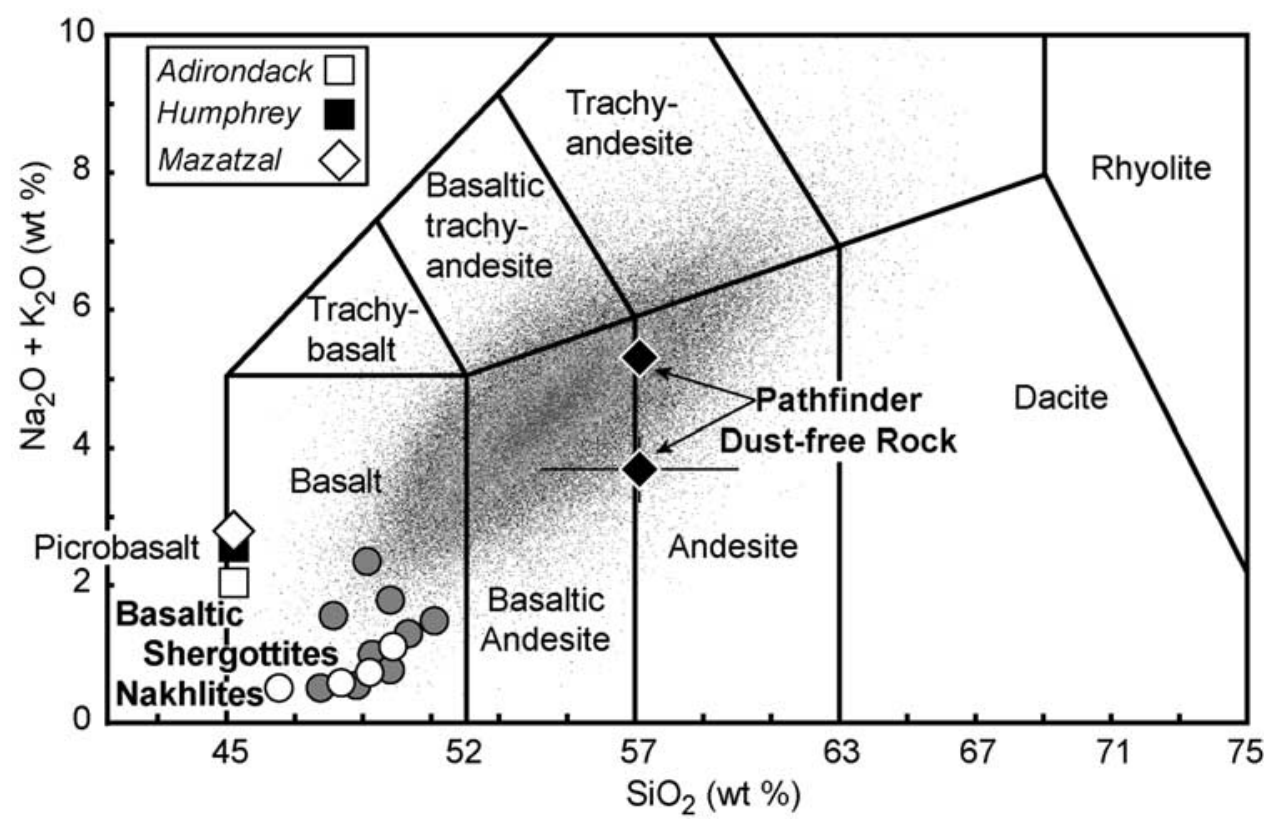

Figure 9. Alkalis versus silica diagram used for volcanic rock classification. Gusev basalts plot on the boundary between basalt and picrobasalt, distinct from Martian basaltic meteorites (shergottites and nakhlites; references in Table 2) and Mars Pathfinder rocks [Brückner et al., 2003; Foley et al., 2003]. The cloud of points represents global surface compositions estimated from TES spectra, as described by McSween et al. [2003].

(Dhofar 019 and Yamato 980459) contain euhdral olivine megacrysts having magnesian core compositions $\left(\mathrm{Fo}_{83-86}\right)$ that are in equilibrium with the bulk-rock compositions [Taylor et al., 2002; Greshake et al., 2004; Mikouchi et al., 2004]. Crystal size distribution (CSD) analyses of olivines for the most part produce linear arrays [Taylor et al., 2002; Goodrich, 2003; Greshake et al., 2004], supporting the hypothesis that most olivines formed by continuous cooling without interruption. These data support the hypothesis that the olivine megacrysts are phenocrysts.

[34] A complicating factor is that even Dhofar 019 and Yamato 980459 contain a few corroded, Fe-rich olivines, and their CSD patterns deviate from the linear trend at the largest grain sizes [Goodrich, 2003; Greshake et al., 2004]. These unusual grains are possibly xenocrysts or cumulates, but they comprise only a small portion of the olivine megacryst population in each meteorite. A further complication is that, for most olivine-phyric shergottites, the earliest crystallizing olivine phenocrysts (those with compositions in equilibrium with the bulk-rock magma composition) are missing, apparently removed by crystal fractionation [Goodrich, 2003]. Taking all the data into account, the most plausible model is that the bulk of olivine crystals in olivine-phyric shergottites are phenocrysts. In many of these meteorites, the earliest-formed phenocrysts have been lost and some small proportion of xenocrysts or cumulates have been added. However, the most magnesian olivine-phyric shergottites like Yamato 980459 appear to represent liquid compositions, or nearly so.

[35] As expected, olivine-phyric shergottites have higher contents of magnesium and nickel than do basaltic shergottites (Figure 13a). Given the model above, this correlation can be interpreted as reflecting the higher magnesium and nickel abundances in primitive magmas, with the trend representing an olivine-control fractionation line. The Gusev basalts Humphrey, Adirondack, and Mazatzal plot near the olivine-phyric shergottites in Figure 13a. All the Martian rocks have higher magnesium contents at a given nickel content than terrestrial mafic and ultramafic rocks (Figure 13a). Gusev basalts also have magnesium-chromium ratios that are similar to olivine-phyric shergottites (Figure 13b). In this case, chromium occurs

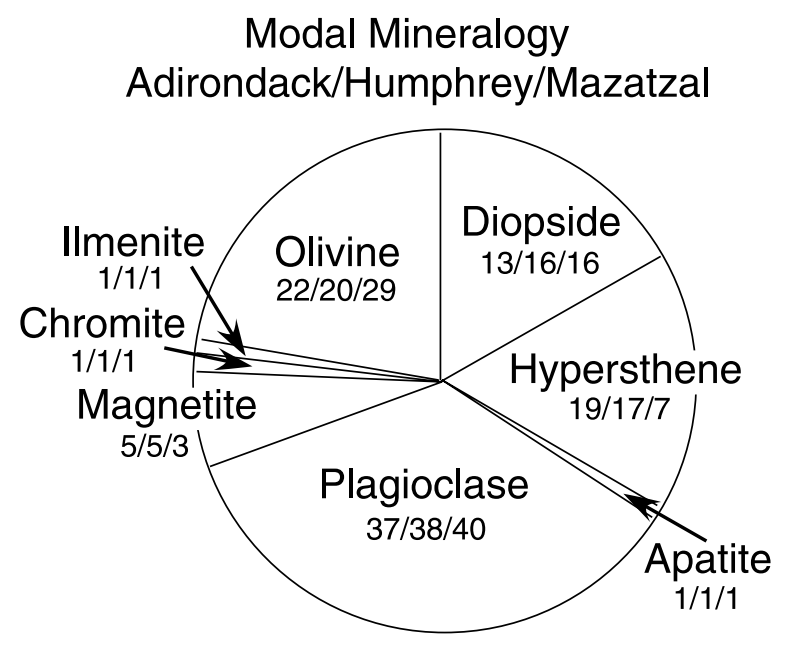

Figure 10. Calculated normative mineralogy for Adirondack, Humphrey, and Mazatzal (Table 1). Mineral abundances $(w t \%)$ are given, in order, for each of the analyzed rocks. 
(a) Olivine Compositions

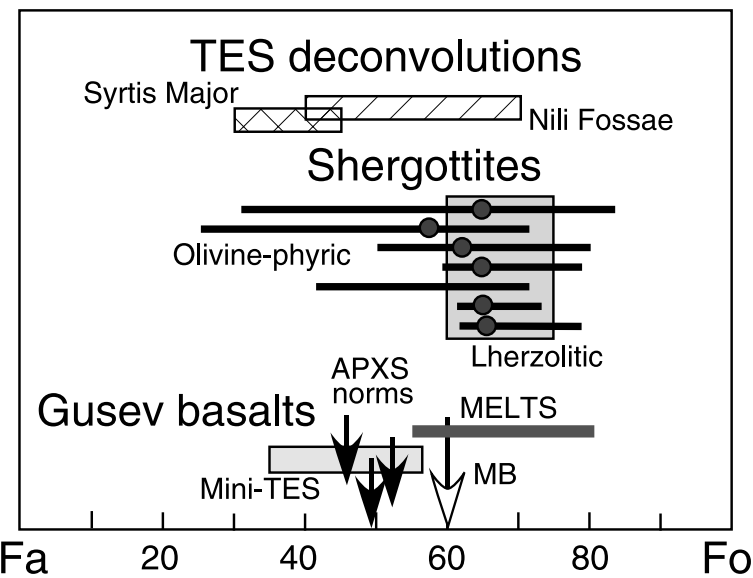

(b) Olivine Proportions

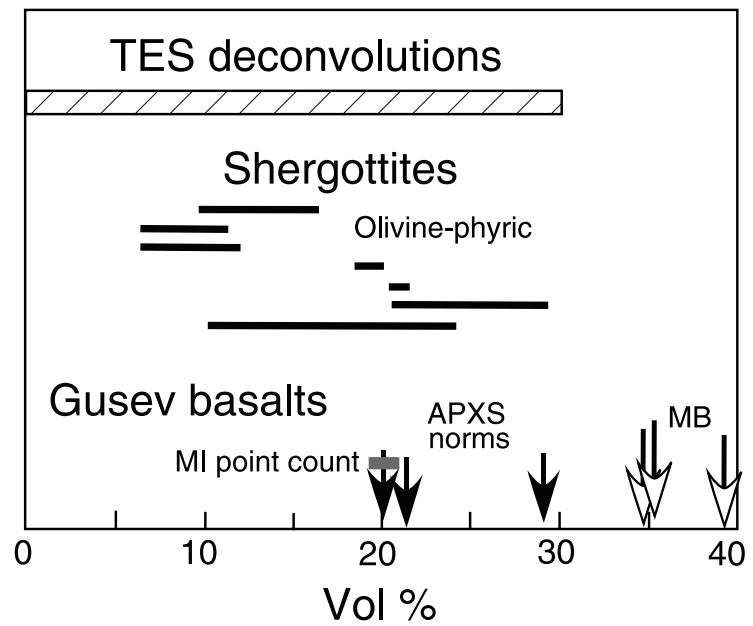

Figure 11. (a) Comparison of olivine compositions (mol\% forsterite $\mathrm{Mg}_{2} \mathrm{SiO}_{4}$ ) for Adirondack, Humphrey, and Mazatzal measured by MiniTES and Mössbauer (MB) spectroscopy and APXS normative calculations with electron probe analyses for olivines in olivine-phyric and lherzolitic shergottites (references in Table 2). The shaded circles on olivine-phyric shergottite range bars are the normative olivine compositions for those meteorites (Table 2). The bar labeled MELTS represents the range of olivine compositions predicted to crystallize from Gusev basalt magmas (see text). Also shown are the ranges of olivine compositions determined from orbital TES spectra [Hoefen et al., 2003; Hamilton et al., 2003]. (b) Comparison of olivine abundances in Adirondack, Humphrey, and Mazatzal with point-counts of olivine-phyric shergottites (Table 2; ranges reflect counts of multiple thin sections) and olivine abundances estimated from TES spectra [Hoefen et al., 2003].

dominantly in associated spinel (also an early crystallizing phase; see section 6.1) rather than being hosted in olivine.

[36] The tight clustering of Gusev basalt compositions may provide a further argument that the olivines they contain are phenocrysts. Incorporation of xenocrysts or cumulates would likely be a random process, producing
Table 2. Properties of Olivine in Olivine-Phyric Shergotttites

\begin{tabular}{lcccl}
\hline & $\begin{array}{c}\text { Compositional } \\
\text { Range, } \\
\text { \% Fo }\end{array}$ & $\begin{array}{c}\text { Abundance, } \\
\text { vol\% }\end{array}$ & $\begin{array}{c}\text { Normative } \\
\text { Composition, } \\
\text { \% Fo }\end{array}$ & References $^{\text {b }}$ \\
\hline Meteorite & $72-25$ & $7-12$ & 57 & $(1)$ \\
Dho 019 & $81-52$ & $7-13$ & 62 & $(2),(3)$ \\
EETA 79001 & $79-62$ & $10-24$ & 66 & $(4-7)$ \\
DaG 476 & & & \\
DaG 489 & $79-59$ & $18-20$ & 66 & $(6),(8)$ \\
SAU 005 & $74-62$ & $21-29$ & 65 & $(9)$ \\
NWA 1068 & $72-42$ & 21 & d & $(10)$ \\
Y-980459 & $84-31$ & $9-16$ & 65 & $(11-14)$ \\
\hline
\end{tabular}

${ }^{\mathrm{a}}$ Norm calculations assume $\mathrm{Fe}^{2+} / \mathrm{Fe}($ total $)=0.84$, as in Humphrey [Morris et al., 2004].

${ }^{b}$ References: (1) Taylor et al. [2002], (2) Steele and Smith [1982], (3) McSween and Jarosewich [1983], (4) Zipfel et al. [2000], (5) Mikouchi et al. [2001], (6) Wadhwa et al. [2001], (7) Koizumi et al. [2004], (8) Folco et al. [2000], (9) Goodrich [2003], (10) Barrat et al. [2002], (11) Greshake et al. [2004], (12) Ikeda [2004], (13) Mikouchi et al. [2004], (14) Shirai and Ebihara [2004].

'Probably paired, along with DaG 670, 735, 876, 975.

${ }^{\mathrm{d}}$ No silica analysis reported, so norm cannot be calculated.

variable proportions of megacrysts and varying bulk rock chemistry. Despite apparent differences in modal olivine contents in Adirondack, Humphrey, and Mazatzal, their chemical compositions are nearly uniform.

\subsection{Orbital Spectroscopy and Regional/Global Context}

[37] The Thermal Emission Spectrometer (TES) on Mars Global Surveyor has provided unprecedented insights into the composition of broad areas of the Martian surface. A detailed study of atmospherically corrected spectra [Smith et al., 2000] in Cimmeria Terra by Christensen et al. [2000] identified basaltic surface compositions dominated by plagioclase $(45 \%$ and $53 \%)$ and high-calcium pyroxene $(26 \%$ and $19 \%$ ) with detectable amounts of olivine (12\%). Further analyses [Hoefen et al., 2003; Hamilton and Christensen, 2005] of TES spectra using several intermediate olivine

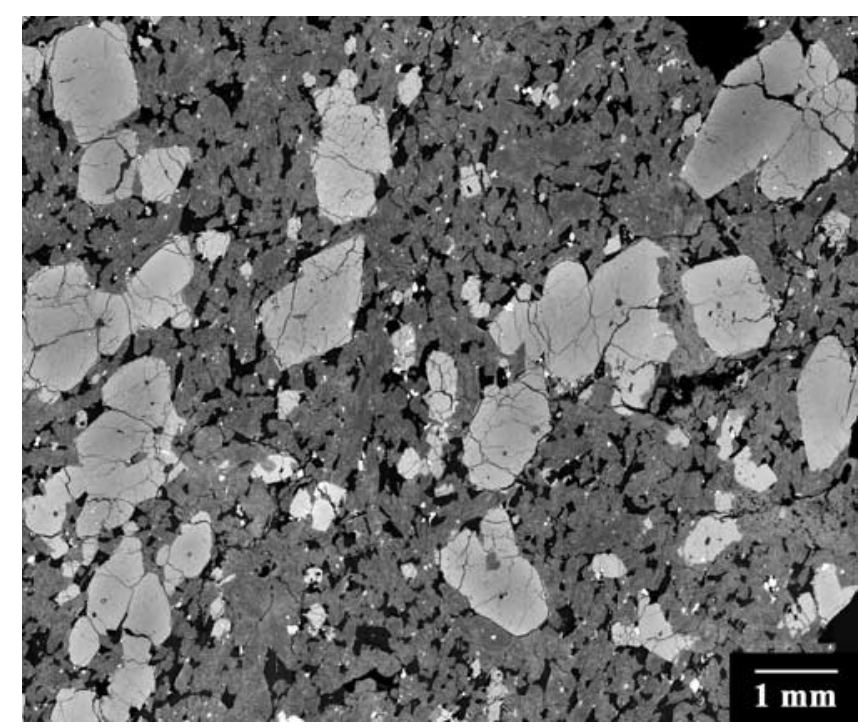

Figure 12. Backscattered electron (BSE) image of olivinephyric shergottite SAU 005 showing olivine megacrysts in a groundmass of pyroxenes and plagioclase. Figure is $5.5 \mathrm{~mm}$ across [after Goodrich, 2003]. 

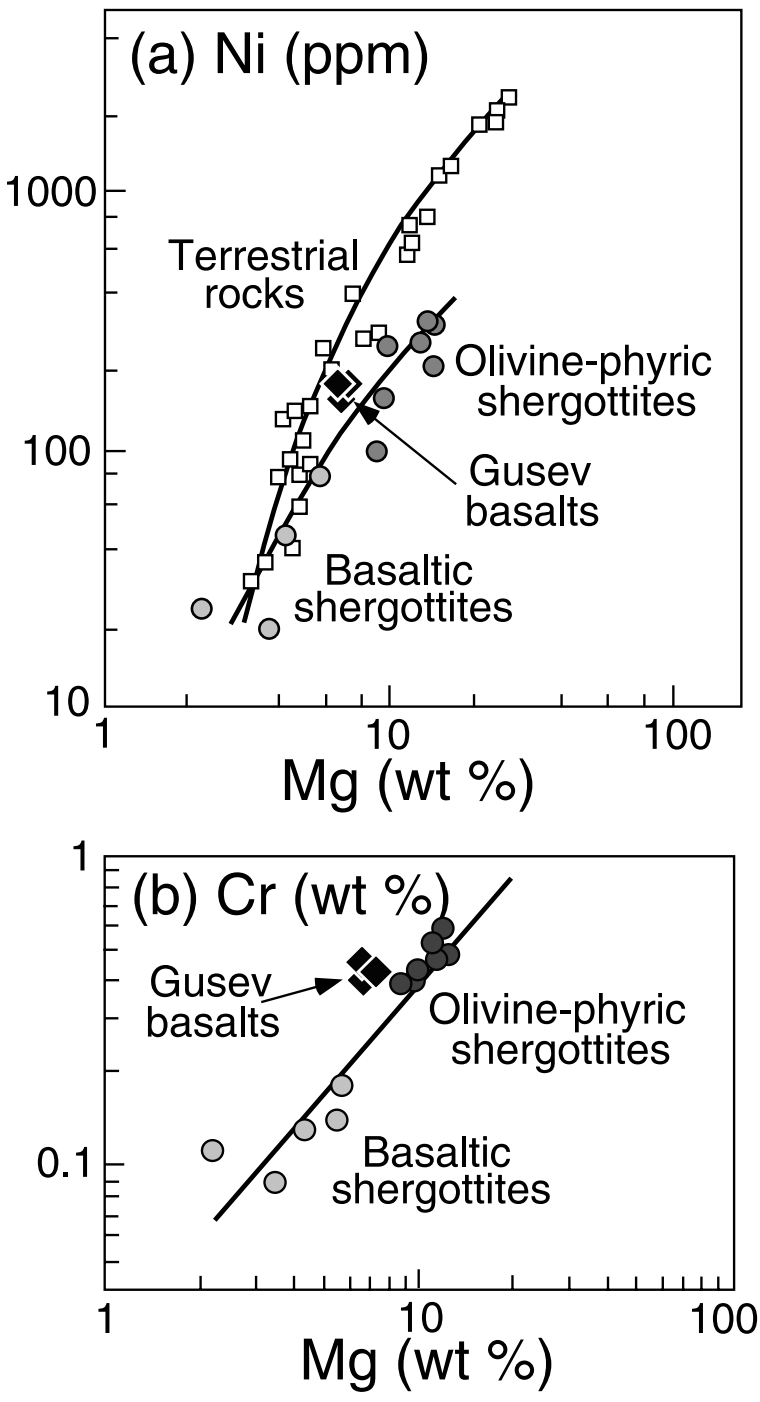

Figure 13. (a) Nickel versus magnesium in Gusev basalts, compared to bulk shergottites and terrestrial basalts and ultramafic rocks (modified from Zipfel et al. [2000]). (b) Chromium versus magnesium in Gusev basalts, compared to bulk shergottites (modified from Wänke and Dreibus [1988]).

compositions suggested that olivine is widespread and abundant in Nili Fossae, a volcanic terrain northeast of Syrtis Major. Mapped olivine compositions in Nili Fossae overlap olivine compositions in Gusev basalts, but olivines in Syrtis Major are more iron-rich (Figure 11a). The olivine composition becomes progressively more iron-rich from west to east across the $30,000 \mathrm{~km}^{2}$ Nili Fossae area, and linear deconvolutions indicate an olivine abundance of $\sim 30 \%$. A study by Hamilton et al. [2003] also found high abundances of olivine in Nili Fossae and local concentrations including but not limited to Gangis Chasma, Aurorae Planum, the Argyre and Hellas basin rims, and Eos Chasma. Rogers et al. [2005] also found several olivine-bearing bedrock units, containing $25 \%$ olivine of composition $\mathrm{Fo}_{60}$, in Ares Vallis using data from TES and the Thermal Emission Imaging System (THEMIS). These authors noted that olivine-phyric shergottites provide the closest compo- sitional match for the Ares Vallis rocks. Their exposure patterns suggest formation as several distinct flows.

[38] Figure 14a shows a THEMIS daytime infrared mosaic of Gusev Crater. Superimposed on the mosaic are the MER Spirit landing ellipse $(\sim 83 \mathrm{~km}$ long by $\sim 10 \mathrm{~km}$ wide) and a TES orbital track (ock 5367, ick 1600-1603) with different colors showing derived surface temperatures ( $3 \times 6 \mathrm{~km}$ spatial resolution). Differential heating of slopes produces a clear picture of the crater rim, Ma'adim Vallis, and mesas in the south. The floor of Gusev Crater, however, displays temperature variations that are independent of topography. Two prominent streaks trending SSE are warmer in the day than the rest of the crater floor and correspond to relatively low albedo, dust-free streaks that are evident in visible images. Their warmer temperatures are due to the differential heating that result from albedo contrast.

[39] An average atmospherically corrected emissivity spectrum of six of the warmest TES pixels (294-296 K) outlined in the THEMIS mosaic is shown in Figure 14b with a linearly deconvolved modeled spectral fit. The abundances of derived minerals that fit the measured spectrum have been summed into mineral groups with accuracies of 5-10 volume $\%$. The end-member spectra shown are scaled by these abundances to show how each contributes to the measured spectrum. The composition of the warm, low-albedo streak is dominated by plagioclase $(45 \%)$ and clinopyroxene $(30 \%)$ with $15 \%$ olivine. This bulk mineralogy agrees well with the MiniTES-derived composition (section 4.2) of dark disturbed soils $(50 \%$ plagioclase, $40 \%$ clinopyroxene, and $10 \%$ olivine) and indicates a regional similarity in basaltic compositions in Gusev Crater.

[40] Figure 15 shows a new global map of olivine abundances on Mars derived from atmospherically corrected TES data, overlain on a color mosaic. Recent work [Hamilton and Schneider, 2005] has led to four additional intermediate to ferroan olivine composition $\left(\mathrm{Fo}_{68}, \mathrm{Fo}_{60}\right.$, $\mathrm{Fo}_{35}$, and $\mathrm{Fo}_{10}$ ) spectral end-members that can be used to detect and model olivine abundances more accurately. TES emissivity spectra were binned and averaged at 4 pixels/ degree (15 km/pixel) [Bandfield, 2002] and linearly deconvolved from $1301-825 \mathrm{~cm}^{-1}$ and $508-233 \mathrm{~cm}^{-1}$ using a spectral end-member set that includes a broad range of igneous and sedimentary minerals, Martian atmospheric dust and water ice [Bandfield et al., 2000b], and epf (emission phase function)-derived Martian surface dust [Bandfield and Smith, 2003]. The new TES olivine map shows detectable amounts of olivine (10-15 volume \%) in broad near-equatorial regions and corresponds well with the highest mapped abundances of the global TES basalt unit [Bandfield et al., 2000a]. This result is consistent with previous work by Christensen et al. [2000] which modeled $12 \%$ olivine for basaltic surface compositions. The global olivine map also resolves higher olivine abundances (35-50 volume\%) detected in the Nili Fossae region [Hoefen et al., 2003; Hamilton and Christensen, 2005] but does not resolve olivine abundance in Gusev Crater because of the decreased spatial resolution $(15 \mathrm{~km} / \mathrm{pixel})$ of the binned data set and high amount of surface dust.

[41] Results from individual TES spectra of Gusev Crater and globally mapped olivine abundances indicate that large 


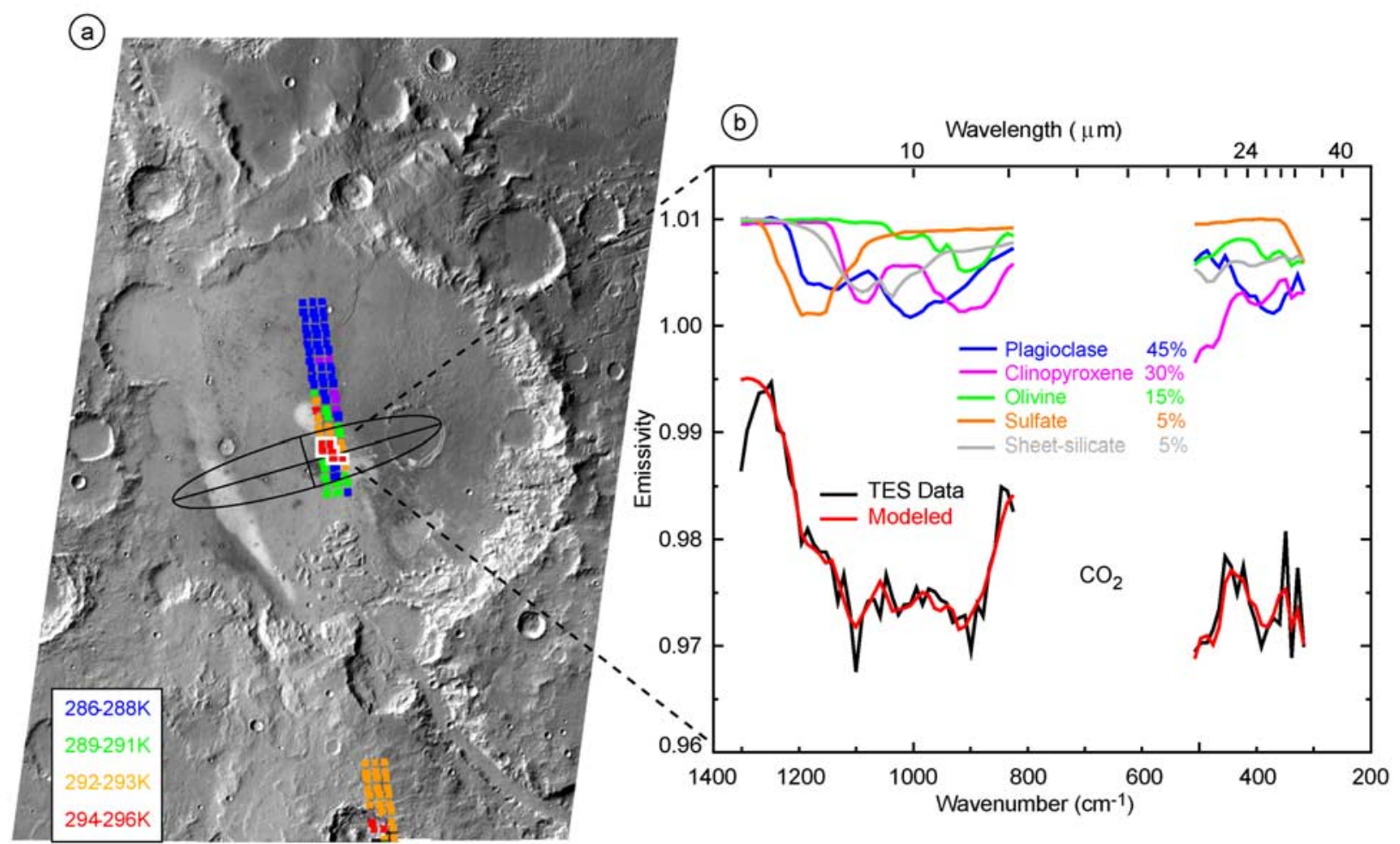

Figure 14. (a) THEMIS daytime infrared mosaic of Gusev Crater with superimposed MER Spirit landing ellipse and TES orbital track showing derived surface temperatures. Temperature variations on the floor of Gusev are due to differential heating that results from albedo contrast. (b) Average atmospherically corrected emissivity spectrum of six of the warmest TES pixels outlined in the THEMIS mosaic with a linearly deconvolved modeled spectral fit. The composition of the warm, low-albedo streak in Gusev Crater agrees well with MiniTES-derived compositions of dark disturbed soils.

expanses of the Martian surface are characterized by olivine-bearing basalts and/or soils with similar compositions.

\section{Discussion}

\subsection{Do Gusev Picritic Basalts Represent Primitive Magmas?}

[42] We have already seen that it is difficult to determine whether the olivines in Gusev basalts are phenocrysts or were added to magmas as xenocrysts or cumulate material. The 1-atm crystallization sequence of a magma having the bulk composition of Humphrey (chosen because it appears to be least altered, based on MI observations and grinding hardness) has been estimated using the MELTS program [Ghiorso and Sack, 1995]. The measured $\mathrm{Fe}^{2+} / \mathrm{Fe}$ (total) value for Humphrey corresponds to an oxidation state close to the quartz-fayalite-magnetite buffer (QFM), so we assumed that oxidation state for this calculation. The results (Figure 16) indicate early crystallization of chromium spinel and then olivine, followed by the near-simultaneous appearance of orthopyroxene, clinopyroxene, plagioclase, and whitlockite. One possible interpretation of the early appearance of olivine and spinel is that both phases accumulated in the magma or were incorporated as xenocrysts.

[43] However, high-pressure experiments reported by Monders et al. [2005] indicate that the Gusev picritic basalt magma composition is multiply saturated with olivine, spinel, and orthopyroxene at $\sim 11 \mathrm{GPa}$, corresponding to a depth in the Martian mantle of $\sim 75 \mathrm{~km}$. This experiment offers strong support for the idea that Gusev basalts represent a primitive magma composition, formed by $\sim 20 \%$ melting of an undepleted mantle source. Other subsolidus experiments are consistent with a Martian mantle of olivine + orthopyroxene + spinel at this depth [Bertka and Holloway, 1994]. This magma may have experienced little or no fractionation during ascent and emplacement, but instead underwent equilibrium crystallization at or near the surface.

\subsection{Could Gusev Basalts Be} Olivine-Phyric Shergottites?

[44] We previously noted similarities in the modal abundance and composition of olivines in Gusev basalts and olivine-phyric shergottites, as well as in their bulk-rock nickel/magnesium and chromium/magnesium ratios. There is yet another intriguing similarity that should be noted.

[45] Preliminary high-pressure melting experiments on Yamato 980459, the most magnesian olivine-phyric shergottite [Greshake et al., 2004; Mikouchi et al., 2004], indicate co-saturation with olivine and pyroxene at 11$12 \mathrm{GPa}$ [Dalton et al., 2005]. Olivine compositions in the experiment $\left(\mathrm{Fo}_{86}\right)$ match those of the natural olivine cores. Thus Gusev basalts and olivine-phyric shergottites 


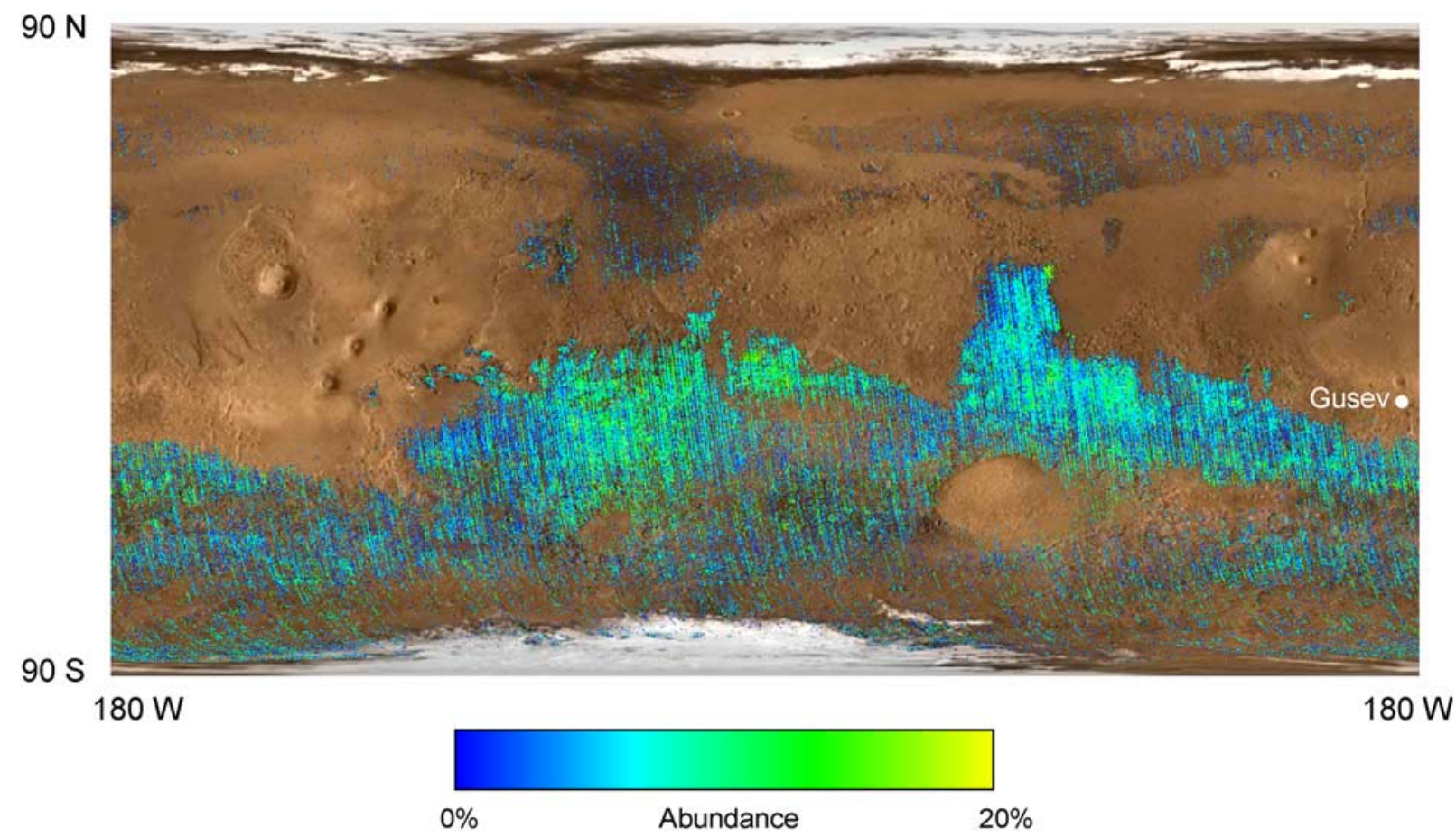

Figure 15. Olivine abundance map of Mars, showing the widespread global distribution of this mineral.

appear to share origins as primitive magmas formed at comparable mantle depths.

[46] Nonetheless, there are some significant compositional differences between these rocks. Shergottites have lower $\mathrm{Al}_{2} \mathrm{O}_{3}$ and $\mathrm{Na}_{2} \mathrm{O}$ (reflected in lower plagioclase abundance) and higher $\mathrm{SiO}_{2}$ (Figure 9) than Gusev basalts. On a $\mathrm{Ca} / \mathrm{Si}$ versus $\mathrm{Mg} / \mathrm{Si}$ diagram used for classification of Martian meteorites [Oura et al., 2003], Gusev basalts do not plot within any part of the olivine-phyric shergottite field, nor any other shergottite field (Figure 17). Also, the Gusev basalts commonly contain vesicles and vugs (Figure 2e), testifying to much higher contents of volatiles on eruption, relative to the olivine-phyric shergottites which do not contain vesicles and were essentially dry.

[47] More importantly, there are apparent age differences. The measured radiometric ages of olivine-phyric shergottites range from 175 to $575 \mathrm{Ma}$ [Nyquist et al. 2001; Borg et al., 2001], corresponding to the Late Amazonian period. Although no specific sources for these meteorites have been determined, they probably were derived from impact craters in the Tharsis or Elyssium volcanic provinces, based on the relatively young crater counting ages for these areas [McSween, 2002] and their lack of detection in spectral studies of Martian dark regions [Hamilton et al., 2003]. Martínez-Alonso et al. [2005] suggested that Gusev basalts likely erupted from Apollinaris Patera, based on the presence of flows on the volcano's southern flank and the existence of a favorable path through the northwest rim of Gusev (now blocked by a younger crater). Such lavas would have to travel $\sim 250 \mathrm{~km}$ up a significant topographic gradient, so this source is problematic. However, the calculated viscosity for Gusev basalt compositions [Greeley et al., 2005] suggests these flows may have been more fluid than terrestrial lavas and comparable to mare lavas on the

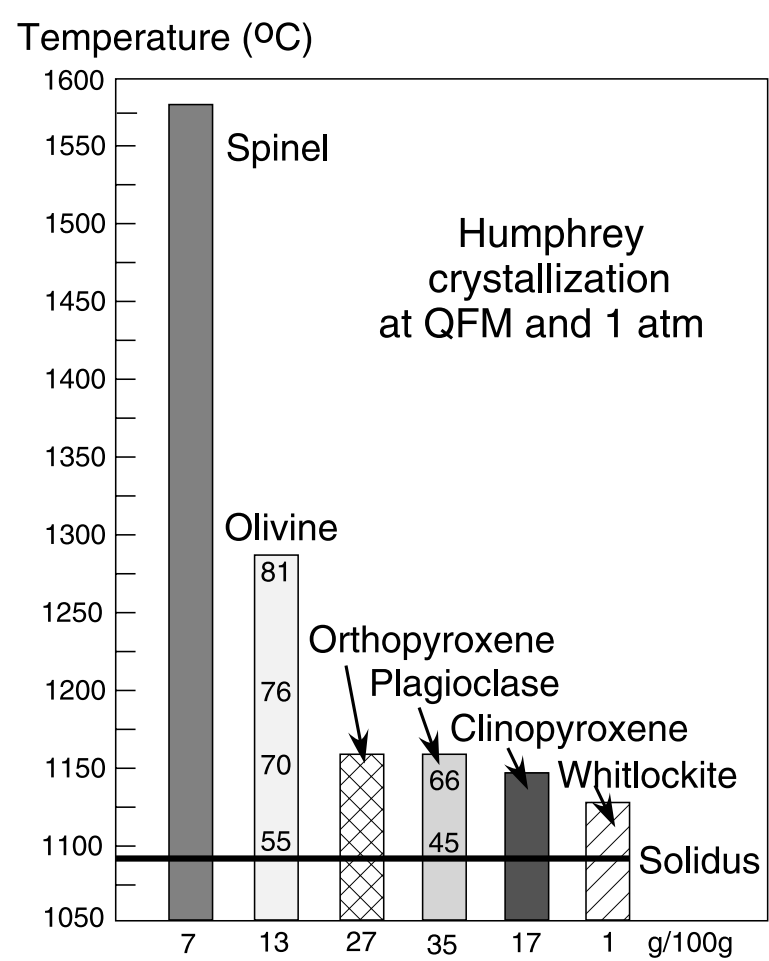

Figure 16. Calculated equilibrium crystallization sequence for a magma having the bulk composition of Humphrey at an oxidation state corresponding to QFM, using the MELTS program. The compositions of olivine ( $\mathrm{mol} \%$ forsterite) and plagioclase (mol\% anorthite) during magma crystallization are given on the respective bars, and the total amounts of each phase crystallized ( $\mathrm{g}$ of solid produced per $100 \mathrm{~g}$ of magma) are given at the bottom of the figure. 
Atomic $\mathrm{Ca} / \mathrm{Si}$

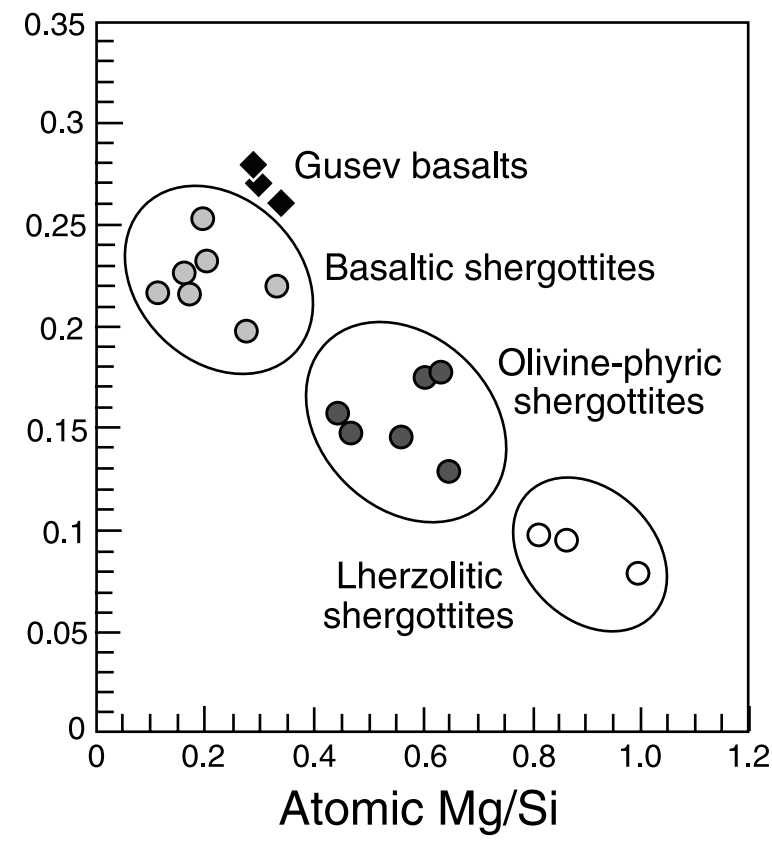

Figure 17. Chemical classification diagram for Martian meteorites [after Oura et al., 2003], illustrating a compositional difference between Gusev basalts and olivine-phyric shergottites.

Moon. There are no obvious volcanic edifices nearer to Gusev, so we cannot specify the source of these flows. Whatever their source, the volcanic units surrounding Apollinaris and the plains unit within Gusev have Hesperian [Milam et al., 2003] or Early Amazonian to Hesperian model ages [Kuzmin et al., 2000], significantly older than olivine-phyric shergottites. Morphological data and crater counts from orbital imagery suggest that lavas flooded Gusev at $\sim 3.65 \mathrm{Ga}$, postdating other materials such as putative sediments emplaced by Ma'adim Vallis [Greeley et al., 2005].

[48] The differences in composition and age appear to rule out any direct petrogenetic relationship between Gusev picritic basalts and shergottites. However, it seems clear that undepleted Martian mantle sources have produced primitive magmas over much of post-Noachian time.

\subsection{Are Rocks Formed From Primitive Magmas Widespread on Mars?}

[49] There are conflicting views about whether the Martian crust is dominated by basalt [Wyatt and McSween, 2002; McSween et al., 2003] or contains significant amounts of andesitic rocks [Bandfield et al., 2000a; Hamilton et al., 2001]. Even the basalt-only advocates, however, have not argued that primitive basalts might be abundant. Primitive, mantle-derived magmas are uncommon on Earth, because most magmas experience fractionation and sometimes contamination with crust en route to the surface. In identifying primitive magmas, even olivine-rich basaltic rocks can be misleading, because they may be fractionated basalts containing cumulus olivine. Yet, the very limited surface exploration of Mars by rovers and the probable biased sampling of the surface by Martian meteorites may have both found instances of rocks formed by solidification of primitive, olivine-rich magmas. The identification of other olivine-bearing volcanic materials from orbital thermal emission spectra further suggests that primitive magmas may not be unusual. Picritic basalts may even be common, because Martian weathering under acidic conditions preferentially attacks olivine [Hurowitz et al., 2006; Schröder et al., manuscript in preparation, 2006] and disguises such rocks under alteration rinds, as observed at Gusev.

\section{Summary}

[50] Volcanic rocks excavated from craters on the floor of Gusev Crater are uniform in composition. These picritic basalts share many similarities with olivine-phyric shergottites, including the following:

[51] 1. Intermediate to ferroan olivine compositions: Gusev basalts contain olivines with average compositions in the range $\mathrm{Fo}_{60-40}$; shergottites contain normally zoned olivines ranging from $\mathrm{Fo}_{84}$ to $\mathrm{Fo}_{25}$ (zoning within individual meteorites is more restricted) with normative olivine compositions of $\sim \mathrm{Fo}_{65}$.

[52] 2. Olivine modal abundances ranging up to 2030 volume $\%$.

[53] 3. Coexisting minerals that include low-calcium and high-calcium pyroxenes, plagioclase of intermediate composition, iron-titanium-chromium oxides, and phosphate.

[54] 4. Porphyritic textures produced by olivine megacrysts.

[55] 5. Similar nickel-magnesium and chromium-magnesium systematics.

[56] 6. Major element bulk-rock compositions that are multiply saturated with olivine, orthopyroxene, and spinel at mantle pressures, suggesting they are primitive magmas.

[57] A number of differences are also apparent:

[58] 1. Textures: Gusev basalts have abundant vesicles and vugs, suggesting eruption with high volatile contents.

[59] 2. Chemical compositions: Gusev basalts have higher $\mathrm{Al}_{2} \mathrm{O}_{3}$ and $\mathrm{Na}_{2} \mathrm{O}$ contents, reflected in higher plagioclase abundances than in shergottites, and they do not plot with shergottites on a $\mathrm{Ca} / \mathrm{Si}$ versus $\mathrm{Mg} / \mathrm{Si}$ classification diagram.

[60] 3. Age: Gusev basalts appear to be Hesperian or Early Amazonian, whereas olivine-phyric shergottites have radiometric ages that are significantly younger (Late Amazonian).

[61] Examination of orbital thermal emission spectra provides a global context for olivine-rich basaltic rocks. Such rocks, containing intermediate to ferroan olivine with abundances up to $30 \%$, appear to be widely distributed within the ancient highlands of Mars. The existence of younger picritic basalts, although clearly demonstrated by olivine-phyric shergottites, has not been confirmed by spectroscopy, probably because young volcanic terrains in Tharsis and Elyssium (likely sources for shergottites) are obscured by dust cover. Nevertheless, primitive olivine-rich basalts of various ages have now been suggested by rover exploration at Gusev Crater, studies of Martian meteorites, and orbital remote sensing. Given that weathering processes under acidic conditions preferentially destroy olivine and 
obscure primary rock mineralogy under alteration rinds, olivine-rich basalts formed from primitive magmas may constitute a significant portion of the Martian crust.

[62] Acknowledgments. We appreciate constructive reviews by J. Barrat and an anonymous reviewer. Funding for Athena science team members was provided by NASA contracts through Cornell and the Jet Propulsion Laboratory. This paper was also supported by NASA Cosmochemistry grant NAG5-12896 to H.Y.M. Some of this work was carried out at and for the Jet Propulsion Laboratory, California Institute of Technology, sponsored by the National Aeronautics and Space Administration.

\section{References}

Adams, J. B. (1974), Visible and near-infrared diffuse reflectance spectra of pyroxenes as applied to remote sensing of solid objects in the solar system, J. Geophys. Res., 79, 4829-4836.

Bandfield, J. L. (2002), Global mineral distributions on Mars, J. Geophys. Res., 107(E6), 5042, doi:10.1029/2001JE001510

Bandfield, J. L., and M. S. Smith (2003), Multiple emission angle surfaceatmosphere separations of thermal emission spectrometer data, Icarus, $161,47-65$.

Bandfield, J. L., V. E. Hamilton, and P. R. Christensen (2000a), A global view of Martian surface compositions from MGS-TES, Science, 287, $1626-1630$.

Bandfield, J. L., P. R. Christensen, and M. D. Smith (2000b), Spectral data set factor analysis and end-member recovery: Application to Martian atmospheric particulates, J. Geophys. Res., 105, 9573-9588.

Barrat, J. A., A. Jambon, M. Bohn, Ph. Gillet, V. Sautter, C. Göpel, M. Lesourd, and F. Keller (2002), Petrology and chemistry of the picritic shergottite North West Africa 1068 (NWA 1068), Geochim. Cosmochim. Acta, 66, 3505-3518.

Bartlett, P. W., L. E. Carlson, P. C. Chu, K. R. Davis, S. Gorevan, A. G. Kusack, T. M. Myrick, and J. J. Wilson (2005), Summary of Rock Abrasion Tool (RAT) results pertinent to the Mars Exploration Rover science data set, Lunar Planet. Sci. [CD-ROM], XXXVI36, abstract 2292.

Bell, J. F., III, et al. (2004), Pancam multispectral imaging results from Spirit rover at Gusev Crater, Science, 305, 800-810

Bell, J. F., III, J. Joseph, J. N. Sohl-Dickstein, H. M. Arneson, M. J. Johnson, M. T. Lemmon, and D. Savransky (2006), In-flight calibration and performance of the Mars Exploration Rover Panoramic Camera (Pancam) instruments, J. Geophys. Res., 111, E02S03, doi:10.1029/ 2005JE002444.

Bertka, C. M., and J. R. Holloway (1994), Anhydrous partial melting of an iron-rich mantle, I.: Subsolidus phase assemblages and partial melting phase relations at 10 to $30 \mathrm{kbar}$, Contrib. Mineral. Petrol., 115, 313-322.

Borg, L. E., L. E. Nyquist, Y. Reese, H. Wiesmann, C.-Y. Shih, M. Ivanova, and L. A. Taylor (2001), The age of Dhofar 019 and its relationship to other Martian meteorites, Lunar Planet. Sci. [CD-ROM], XXXII, abstract 1144.

Brückner, J., G. Dreibus, R. Rieder, and H. Wänke (2003), Refined data of Alpha Proton X-ray Spectrometer analyses of soils and rocks at the Mars Pathfinder site: Implications for surface chemistry, J. Geophys. Res., 108(E12), 8094, doi:10.1029/2003JE002060.

Christensen, P. R., J. L. Bandfield, M. D. Smith, V. E. Hamilton, and R. N. Clark (2000), Identification of a basaltic component on the Martian surface from Thermal Emission Spectrometer data, J. Geophys. Res., 105, 9609-9621.

Christensen, P. R., et al. (2004), Initial results from the Mini-TES experiment in Gusev Crater from the Spirit rover, Science, 305, 837-842.

Cloutis, E. A., and J. F. Bell III (2003), Mafic silicate mapping on Mars: Effects of palagonite, multiple mafic silicates, and spectral resolution, Icarus, 172, 233-254.

Dalton, H. A., D. S. Musselwhite, W. S. Kieffer, and A. H. Treiman (2005), Experimental petrology of the basaltic shergottite Yamato 980459: Implications for the thermal structure of the Martian mantle, Lunar Planet Sci. [CD-ROM], XXXVI, abstract 2142.

Folco, L., I. A. Franchi, M. D’Orazio, S. Rocchi, and L. Schultz (2000), A new Martian meteorite from the Sahara: The shergottite Dar al Gani 489 , Meteorit. Planet. Sci., 35, 827-839.

Foley, C. N., T. Economou, and R. N. Clayton (2003), Final chemical results from the Mars Pathfinder alpha proton X-ray spectrometer, J. Geophys. Res., 108(E12), 8096, doi:10.1029/2002JE002019.

Gellert, R., et al. (2004), Chemistry of rocks and soils in Gusev crater from the Alpha Particle X-ray Spectrometer, Science, 305, 829-832.

Gellert, R., R. Rieder, J. Brückner, B. C. Clark, G. Dreibus, G. Lugmair, D. Ming, H. Wänke, A. Yen, and J. Zipfel (2006), Alpha Particle X-ray Spectrometer (APXS): Results from Gusev crater and calibration report, J. Geophys. Res., doi:10.1029/2005JE002555, in press.
Ghiorso, M. S., and R. O. Sack (1995), Chemical mass transfer in magmatic processes, IV. A revised and internally consistent thermodynamic model for the interpolation and extrapolation of liquid-solid equilibria in magmatic systems at elevated temperatures and pressures, Contrib. Mineral. Petrol., 119, 197-212.

Goodrich, C. A. (2002), Olivine-phyric Martian basalts: A new type of shergottite, Meteorit. Planet. Sci., 37, suppl., B31-B34.

Goodrich, C. A. (2003), Petrogenesis of olivine-phyric shergottites Sayh al Uhaymir 005 and Elephant Moraine A79001 lithology A, Geochim. Cosmochim. Acta, 67, 3735-3771.

Grant, J. A., et al. (2004), Surficial deposits at Gusev Crater along Spirit rover traverses, Science, 305, 807-810.

Greeley, R., B. H. Foing, H. Y. McSween Jr., G. Neukum, P. Pinet, M. van Kan, S. C. Werner, D. A. Williams, and T. E. Zegers (2005), Fluid lava flows in Gusev crater, Mars, J. Geophys. Res., 110, E05008, doi:10.1029/ 2005JE002401.

Greshake, A., J. Fritz, and D. Stöffler (2004), Petrology and shock metamorphism of the olivine-phyric shergottite Yamato 980459: Evidence for a two-stage cooling and a single-stage ejection history, Geochim. Cosmochim. Acta, 68, 2359-2377.

Hamilton, V. E., and P. R. Christensen (2005), Evidence for extensive, olivine-rich bedrock on Mars, Geology, 33, 433-436.

Hamilton, V. E., and R. D. Schneider (2005), Alteration phases associated with high concentrations of orthopyroxene and olivine on Mars, Lunar Planet. Sci. [CD-ROM], XXXVI, abstract 2212.

Hamilton, V. E., M. B. Wyatt, H. Y. McSween, and P. R. Christensen (2001), Analysis of terrestrial and Martian volcanic compositions using thermal emission spectroscopy: 2. Application to Martian surface spectra from the Mars Global Surveyor Thermal Emission Spectrometer, J. Geophys. Res., 106, 14,733-14,746.

Hamilton, V. E., P. R. Christensen, H. Y. McSween, and J. L. Bandfield (2003), Searching for the source regions of Martian meteorites using MGS TES: Integrating Martian meteorites into the global distribution of igneous materials on Mars, Meteorit. Planet. Sci., 38, $871-885$.

Haskin, L. A., et al. (2005), Water alteration of rocks and soils from the Spirit rover site, Gusev Crater, Mars, Nature, 436, 66-69, doi:10.1038/ nature 03640 .

Herkenhoff, K. E., et al. (2004), Textures of the soils and rocks at Gusev Crater from Spirit's Microscopic Imager, Science, 305, 824-826.

Hoefen, T. M., R. N. Clark, J. L. Bandfield, M. D. Smith, J. C. Pearl, and P. R. Christensen (2003), Discovery of olivine in the Nili Fossae region of Mars, Science, 302, 627-630.

Hurowitz, J. A., S. M. McLennan, N. J. Tosca, and the Athena Science Team (2006), In situ and experimental evidence for acidic weathering of rocks and soil on Mars, J. Geophys. Res., 111, E02S19, doi:10.1029/ 2005JE002515.

Ikeda, Y. (2004), Petrology of the Yamato 980459 shergottite, Antarct. Meteorite Res., 17, 35-54.

Koizumi, E., T. Mikouchi, A. Monkawa, and M. Miyamoto (2004), Origin of olivine megacrysts and the groundmass crystallization of the Dar al Gani 476 shergottite, Antarct. Meteorite Res., 17, 84-96.

Kuzmin, R. O., R. Greeley, R. Landheim, N. A. Cabrol, and J. D. Farmer (2000), Geologic map of the MTM-15182 and MTM-15187 quadrangles, Gusev Crater-Ma'adim Vallis region, Mars, U.S. Geol. Surv. Geol. Invest. Ser., Map I-2666, 8 pp., 1 sheet.

Martínez-Alonso, S., B. M. Jakosky, M. T. Mellon, and N. E. Putzig (2005), A volcanic interpretation of Gusev Crater surface materials from thermophysical, spectral, and morphological evidence, J. Geophys. Res., 110, E01003, doi:10.1029/2004JE002327.

McSween, H. Y. (2002), The rocks of Mars, from far and near, Meteorit. Planet. Sci., 37, 7-25.

McSween, H. Y., and E. Jarosewich (1983), Petrogenesis of the Elephant Moraine A79001 meteorite: Multiple magma pulses on the shergottite parent body, Geochim. Cosmochim. Acta, 47, 1501-1513.

McSween, H. Y., Jr., T. L. Grove, and M. B. Wyatt (2003), Constraints on the composition and petrogenesis of the Martian crust, J. Geophys. Res., 108(E12), 5135, doi:10.1029/2003JE002175.

McSween, H. Y., et al. (2004), Basaltic rocks analyzed by the Spirit rover in Gusev Crater, Science, 305, 842-845.

Mikouchi, T., M. Miyamoto, and G. A. McKay (2001), Mineralogy and petrology of the Dar al Gani 476 Martian meteorite: Implications for its cooling history and relationship to other shergottites, Meteorit. Planet Sci., 36, 531-548.

Mikouchi, T., E. Koizumi, G. McKay, A. Monkawa, Y. Ueda, J. Chokai, and M. Miyamoto (2004), Yamato 980459: Mineralogy and petrology of a new shergottite-related rock from Antarctica, Antarct. Meteorite Res. $17,13-34$.

Milam, K. A., K. R. Stockstill, J. E. Moersch, H. Y. McSween Jr., L. L. Tornabene, A. Ghosh, M. B. Wyatt, and P. R. Christensen (2003), 
THEMIS characterization of the MER Gusev crater landing site, J. Geophys. Res., 108(E12), 8078, doi:10.1029/2002JE002023.

Mittlefehldt, D. W., D. J. Lindstrom, M. M. Lindstrom, and R. R. Martinez (1999), An impact-melt origin for lithology A of Martian meteorite Elephant Moraine A79001, Meteorit. Planet. Sci., 34 $357-367$.

Monders, A. G., E. Medard, and T. L. Grove (2005), Primary Martian basalts at Gusev crater: Experimental constraints, Lunar Planet. Sci. [CD-ROM], XXXVI, abstract 2069.

Morris, R. V., et al. (2000), Mineralogy, composition, and alteration of Mars Pathfinder rocks and soils: Evidence from multispectral, elemental, and magnetic data on terrestrial analogue, SNC meteorite, and Pathfinder samples, J. Geophys. Res., 105, 1757-1817.

Morris, R. V., et al. (2004), Mineralogy at Gusev crater from the Mössbauer Spectrometer on the Spirit rover, Science, 305, 833-836.

Nyquist, L. E., D. D. Bogard, C.-Y. Shih, A. Greshake, D. Stöffler, and O. Eugster (2001), Ages and geologic histories of Martian meteorites, Space Sci. Rev., 96, 105-164.

Oura, Y., N. Shirai, and M. Ebihara (2003), Chemical composition of Yamato (Y)000593 and Y000749: Neutron-induced prompt gamma-ray analysis study, Antarct. Meteorite Res., 16, 80-93.

Rieder, R., T. Economou, H. Wänke, A. Turkevich, J. Crisp, J. Brückner, G. Dreibus, and H. Y. McSween (1997), The chemical composition of Martian soil and rocks returned by the mobile Alpha-Proton-X-ray Spectrometer: Preliminary results from the x-ray mode, Science, 278, $1770-1774$

Robinson, M. S., and P. J. Mouginis-Mark (1993), Chronology, eruption duration, and atmospheric contribution of the Martian volcano Apollinaris Patera, Icarus, 104, 301-323.

Rogers, A. D., P. R. Christensen, and J. L. Bandfield (2005), Compositional heterogeneity of the ancient Martian crust: Analysis of Ares Vallis bedrock with THEMIS and TES data, J. Geophys. Res., 110, E05010, doi:10.1029/2005JE002399.

Shirai, N., and M. Ebihara (2004), Chemical characteristics of a Martian meteorite, Yamato 980459, Antarct. Meteorite Res., 17, 55-67.

Smith, M. D., J. L. Bandfield, and P. R. Christensen (2000), Separation of atmospheric and surface spectral features in Mars Global Surveyor thermal emission spectrometer (TES) spectra, J. Geophys. Res., 105, 9589-9607.

Squyres, S. W., et al. (2004), The Spirit rover's Athena science investigation at Gusev Crater, Mars, Science, 305, 794-799.

Steele, I. M., and J. V. Smith (1982), Petrography and mineralogy of two basalts and olivine-pyroxene-spinel fragments in achondrite EETA79001, Proc. Lunar Planet. Sci. Conf. 13th, Part 1, J. Geophys. Res., 87, suppl., A375-A384.

Taylor, L. A., et al. (2002), Martian meteorite Dhofar 019: A new shergottite, Meteorit. Planet. Sci., 37, 1107-1128.

Wadhwa, M., H. Y. McSween, and G. Crozaz (1994), Petrogenesis of shergottite meteorites inferred from minor and trace element microdistributions, Geochim. Cosmochim. Acta, 58, 4213-4229.

Wadhwa, M., R. C. F. Lentz, H. Y. McSween, and G. Crozaz (2001), A petrologic and trace element study of Dar al Gani 476 and Dar al Gani 489: Twin meteorites with affinities to basaltic and lherzolitic shergottites, Meteorit. Planet. Sci., 36, 195-208.

Wänke, H., and G. Dreibus (1988), Chemical composition and accretion history of terrestrial planets, Philos. Trans. R. Soc. London, Ser. A, 325 , $545-557$.

Wyatt, M. B., and H. Y. McSween (2002), Spectral evidence for weathered basalt as an alternative to andesite in the Martian lowlands of Mars, Nature, 417, 263-266.
Zipfel, J., P. Scherer, B. Spettel, G. Dreibus, and L. Schultz (2000), Petrology and chemistry of the new shergottite Dar al Gani 476, Meteorit. Planet. Sci., 35, 95-106.

R. E. Arvidson, B. L. Joliff, and A. Wang, Department of Earth and Planetary Sciences, Washington University, St. Louis, MO 63130-4899, USA. (arvidson@wunder.wustl.edu; blj@levee.wustl.edu; alianw@levee. wustl.edu)

P. Bartlett and S. Gorevan, Honeybee Robotics, 204 Elizabeth Street, New York, NY 10012, USA. (bartlett@honeybeerobotics.com; govervan@ honeybeerobotics.com)

J. F. Bell III and S. W. Squyres, Department of Astronomy, Cornell University, Ithaca, NY 14853-6801, USA. (jfb8@cornell.edu; squyres@ astrosun2.astrosun.cornell.edu)

D. Blaney, J. A. Crisp, M. Golombek, and A. Yen, Jet Propulsion Laboratory, California Institute of Technology, Pasadena, CA 91109-8099, USA. (diana. blaney@jpl.nasa.gov; joy.crisp@jpl.nasa.gov; matt.golombek@jpl.nasa.gov; albert.yen@jpl.nasa.gov)

N. A. Cabrol and D. J. Des Marais, NASA Ames Research Center, Moffett Field, CA 94035-1000, USA. (ncabrol@mail.arc.nasa.gov; david.j.desmarais@nasa.gov)

P. R. Christensen, J. D. Farmer, R. Greeley, A. T. Knudson, S. W. Ruff, and M. B. Wyatt, Department of Geological Sciences, Arizona State University, Tempe, AZ 85287-6305, USA. (phil.christensen@asu.edu; jfarmer@asu.edu; greeley@asu.edu; amy.knudson@asu.edu; steve.ruff@ asu.edu; michael.wyatt@asu.edu)

B. C. Clark, Lockheed Martin Corporation, Littleton, CO 80127, USA. (benton.c.clark@1mco.com)

L. S. Crumpler, New Mexico Museum of Natural History and Science, Albuquerque, NM 87104, USA. (larry_crumpler@mac.com)

P. A. de Souza Jr., Companhia Vale do Rio Doce, 20030-900, Rio de Janeiro, RJ, Brazil. (pasouza03@yahoo.com.br)

T. Economou, Enrico Fermi Institute, University of Chicago, Chicago, IL 60637, USA. (tecon@tecon.uchicago.edu)

W. Farrand, Space Science Institute, 4750 Walnut Street, Boulder, CO 80301, USA. (farrand@colorado.edu)

R. Gellert, R. Rieder, H. Wänke, and J. Zipfel, Max Planck Institut für Chemie, D-55099 Mainz, Germany. (gellert@mpch-mainz.mpg.de; rieder@ mpch-mainz.mpg.de; waenke@mpch-mainz.mpg.de; zipfel@mpch-mainz. mpg.de)

A. Ghosh, H. Y. McSween, K. A. Milam, J. E. Moersch, K. R. Stockstill, and L. Tornabene, Department of Earth and Planetary Sciences, University of Tennessee, Knoxville, TN 37996-1410, USA. (aghosh@cs.utk.edu; mcsween@utk.edu; kmilam@utk.edu; jmoersch@utk.edu; kstockst@utk. edu; 1tornabe@utk.edu)

V. E. Hamilton, Hawai'i Institute of Geophysics and Planetology, University of Hawai'i, Honolulu, HI 96822, USA. (hamilton@higp. hawaii.edu)

K. E. Herkenhoff and J. R. Johnson, U.S. Geological Survey, Flagstaff, AZ 86001-1698, USA. (kherkenhoff@usgs.gov; jrjohnson@usgs.gov)

G. Klingelhöfer and C. Schröder, Institut für Anorganische und Analytische Chemie, Johannes Gutenberg-Universität, Staudinger Weg 9, D-55128 Mainz, Germany. (klingel@mail.uni-mainz.de; schroedc@unimainz.de)

S. McLennan, Department of Geosciences, State University of New York, Stony Brook, NY 11794-2100, USA. (scott.mclennan@sunysb.edu)

D. Ming and R. V. Morris, NASA Johnson Space Center, Houston, TX 77058, USA. (douglas.w.ming1@jsc.nasa.gov; richard.v.morris@nasa.gov) 